\title{
Accuracy of dental implants inserted in clinical studies using static implantation guides: a systematic review and a meta-analysis
}

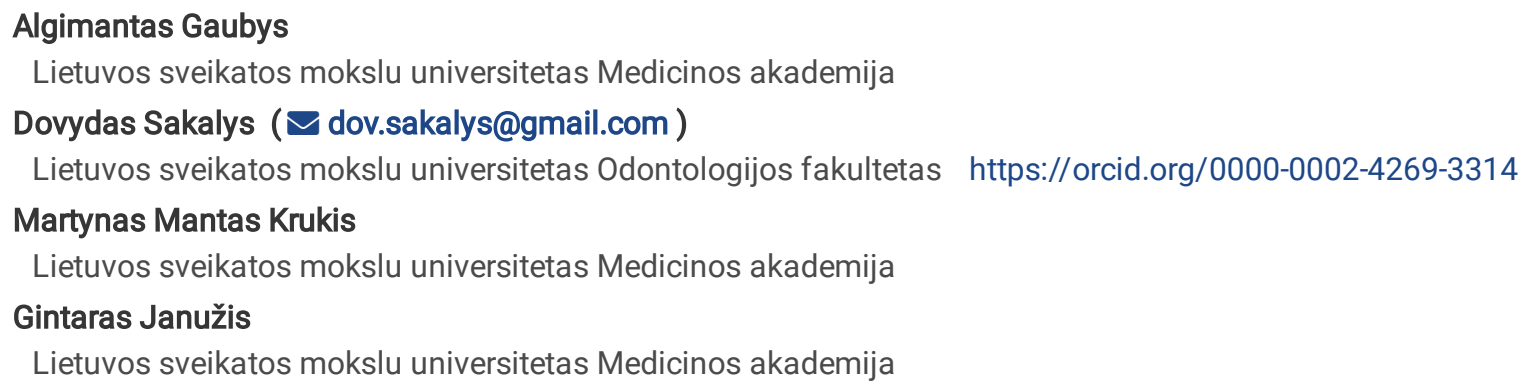

Research article

Keywords: Dental Implant, Computer-Aided Surgery, Cone-Beam Computed Tomography, Software

Posted Date: May 5th, 2020

DOI: https://doi.org/10.21203/rs.3.rs-24045/v1

License: (c) (i) This work is licensed under a Creative Commons Attribution 4.0 International License. Read Full License 


\section{Abstract}

Background One of the main tasks of dental implantation is the precise insertion of the implant into the edentulous jaw. The purpose of a study was to determine the accuracy of implants inserted using static implantation guides in different conditions.

Methods A search for clinical studies was performed in the PubMed databasis. The implantation procedure had to be performed on humans in vivo by using a static surgical guide. Pre and postsurgical CT scans were compared to evaluate the deviation of implants. A meta-analyses was performed to calculate the mean implant collar, apex, depth and axis deviations. A meta-regression analyses was performed by grouping study subgroups according to the method of surgery, implant insertion, jaw, guide support tissue, and the method of guide fixation.

Results 19 studies were included in the meta-analysis. Data on 1872 implants were analyzed. Mean deviation was $1.25 \mathrm{~mm}$ (95\% Cl: 1.00 , $1.51)$ at the implant entry point and $1.52 \mathrm{~mm}(95 \% \mathrm{Cl}: 1.18,1.86)$ at the apex. Mean axis deviation was $3.47 \mathrm{o}(95 \% \mathrm{Cl}$ : 3.01, 3.94). Depth deviation was $0.15 \mathrm{~mm}(95 \% \mathrm{Cl}:-0.36,0.66)$. The following factors had a positive influence on the implant precision: open surgical technique, fully guided implant insertion and fixation of the surgical guide.

Conclusions The surgical technique, implant insertion method, jaw, guide supporting tissue and fixation has an effect on the deviation of inserted implants.

\section{Background}

One of the main tasks of dental implantation is the precise insertion of the implant into the edentulous jaw. To achieve this, the dental surgeon must perform a comprehensive preoperative examination of the patient. In the past, oral, facial, and maxillofacial surgeons studied implantation areas via orthopantomograms, periapical, bite, cephalometric, and other two-dimensional X-ray images. With the widespread use of computed tomography in clinical dentistry, the first fully guided implantation system [WU8] (NobelProcera / NobelGuide (NobelBiocare, Zurich, Switzerland)) [1] was launched onto the world market in 2005. This system was created in order to improve the clinical outcome of implantation, to equip the surgeon with precise surgical control and to achieve highly accurate implant positions, allowing anatomical insertion in difficult situations [2]. There are currently many different implant planning and insertion systems in implantology. They fall into two main categories: Static implantation guides and dynamic computer navigation [3].

Only static implantation guides are analyzed in this literature review. Using freehand implant placement in complex anatomical areas makes it difficult to regularly achieve the ideal implant position $[4,5]$. In contrast, static implantation guides feature surgical guides that provide an accurate osteotomy, angular positions, and depth. Despite advances in surgical guide planning and manufacturing systems, errors still occur between planned and inserted implant positions [5]. These errors occur for a variety of reasons, e. g. preoperative computed tomography distortions and artefacts $[6,7]$, surgical guide manufacturing errors [5, 8-10], guide position errors during insertion into the oral cavity [11-13], and freedom of movement of osteotomy resulting from mechanical tolerance of the preparatory cylinders [14]. When positioning and fixating the implant on the mucosa, its thickness may also lead to implant position errors $[15,16]$. These errors are caused by anatomical, radiographic, and guide manufacturing technology inaccuracies that are unlikely to be avoided in clinical practice, and therefore, due to technical limitations, the total error of guided implant systems is at least $0.5 \mathrm{~mm}$ [5]. In addition to the error sources mentioned above, other factors that may influence implant accuracy are mentioned in the scientific literature - flapless or open surgical techniques [17], implant insertion with or without a guide [1, 5], surgical guide fixation [5, 17], and type of support tissue [18]. Some authors also suggest that different jaws have influence on the accuracy of implantation $[4,18]$. In the scientific literature, research results on the factors leading to implant position deviations are heterogeneous. Implant deviations in a real clinical situation must be assessed individually, as depending on the anatomical condition, even the smallest deviations of the implant position can cause major postsurgical complications, e.g. in the case of advanced alveolar bone atrophy and a high mandibular canal position, slight deviation of the implant apex may result in mechanical damage to the inferior alveolar nerve [19, 20].

In meta-analyses published in the last 15 years, authors have generally summarized the results of implantation deviations performed in vivo, ex vivo and in vitro conditions. There are no published meta-analyses in scientific databases which investigate the influence of surgical technique and guide fixation on implant position deviations in vivo, while implant depth deviations are rarely ever researched.

\section{Methods}

\section{Protocol and registration}


This systematic review was based on the PRISMA search guide for systematic reviews [21]. The review protocol is registered in the PROSPERO database for systematic reviews [22]. Registration number: CRD42017076584

\section{Search strategy}

The search was performed by one researcher using the MEDLINE (PubMed) data system. Systematic data search combination: dental AND (implant OR implants) AND (guide * OR computer)

Filters used in search:

Studies published between 2012/09/01 and 2019/07/01

In English

Last date for systematic data search: 2019/07/01

During the first stage of the search, titles of publications were read and works that did not fit the topic were rejected. During the second stage, the abbreviations of the publications corresponding to the topic were filtered using the selection and exclusion criteria of research papers. An additional, manual search was carried out using the bibliographies of the selected publications with identical criteria for the selection and exclusion of research papers. In the final stage, texts of the selected publications were read. Based on the criteria for inclusion and exclusion of works from the meta-analysis, selected publications were included in the meta-analysis.

\section{Inclusion and exclusion criteria}

The criteria for inclusion of research papers: (1) types of publications: clinical trials; (2) the subject is static implantation guides; (3) the accuracy of inserted implants is measured; (4) implants inserted in humans in vivo. Criteria for exclusion of research papers: (1) types of publications: literature reviews, meta-analyzes, clinical case studies, pilot studies that describe less than 10 patients; 2) implantation procedures on animals; (3) usage of cheekbones, the sphenoid bone (pterygoids), orthodontic mini-implants; (4) implant position deviations were not measured; (5) in vitro or ex vivo studies. Criteria for inclusion of research papers in meta-analysis: (1) implant osteotomy is prepared using a static surgical guide; (2) preoperative and postoperative computed tomography (CT) was performed on the same X-ray machine using identical parameters; (3) at least 10 patients participated in the study; (4) The position of inserted implants is measured using software and is based on postoperative CT scans; (5) inserted implant deviations are measured in a three-dimensional space; (6) The deviations of inserted implants are indicated in a standardized form (described below). Criteria for exclusion of metaanalysis: (1) static implantation guides used were modified by the author; (2) used dynamic computer assisted implantation; (3) less than 10 had implants inserted; (4) implant osteotomy preparation was completed by the freehand placement technique; (5) no preoperative or postoperative CT control; 6) implant deviations were measured without implant insertion; (7) The deviations of inserted implants are measured in a two-dimensional space.

\section{Data extraction:}

A standardized form was used for data sampling. The data criteria of the publications is as follows:

Number of patients undergoing surgery

Number of inserted implants

Implant planning systems

Implanted jaw

Implant surgical technique (open or closed)

- Implant insertion methods (with or without guide)

Type of implant guide supporting tissue (mucosa, bone, teeth, combined) 
Guide fixation method

Deviation of inserted implant position from planned position:

Q Linear deviation at centre of implant apex and collar

Q Linear implant depth deviation

$\otimes$ Angular deviation of implant axis

Deviation measurement standards:

The linear deviations of the implant position had to be measured between the centres of the apex and collar of the planned and inserted implants, calculating the global deviation - the distance between two points in a three-dimensional space. Global deviation is calculated in accordance with the distances in the buccolingual, mesiodistal, and apicocoronal planes. Linear depth deviations had to be measured in the apicocoronal plane by measuring the vertical distance between the centres of the planned and inserted implant collars. Depth deviations were given as positive values if the implants were drilled too deep. If the implants were not inserted deep enough, the depth deviation was given as a negative value. In publications, all linear deviations are presented in millimetres or micrometres, while in the metaanalysis linear data is presented in millimetres. The angular deviation had to be measured in a three-dimensional space by drawing out the centre line passing through the centres of the implant collar and apex (axes) and measuring the angle formed between the intersected axes of the planned and inserted implants (Fig. 1). Angular deviations were measured in degrees. All deviations had to be established using hardware comparing pre- and post-implantation CTs. If in the publications linear collar and apex deviations were measured separately in the three planes and did not include global deviations, the following mathematical formulas were used to standardize the results, and the global deviation and the standard deviation of said deviation were calculated manually. The calculations were performed twice. If the results did not match, they were calculated a third time.

Data that did not meet the standards used in this study was exluded from the meta-analysis.

$$
3 D \text { dev }=\sqrt{x^{2}+\mathrm{y}^{2}+\mathrm{z}^{2}}
$$

3Ddev = Global Deviation

$\mathrm{x}=$ Deviation in mesiodistal plane

$y=$ Deviation in buccolingual plane

$\mathrm{z}=$ Deviation in apicocoronal plane

$$
\begin{aligned}
& \mathrm{SDcomb}=\sqrt{\left(\mathrm{Nx}\left(\mathrm{SDx}^{2}=(\mathrm{x}-3 \mathrm{Ddev})^{2}\right)+\mathrm{Ny}\left(\mathrm{SDy}^{2}+\right.\right.} \\
& \frac{\sqrt{\left.\left.(y-3 D \operatorname{dev})^{2}\right)+N z\left(S D z^{2}+(z-3 D \operatorname{dev})^{2}\right)\right)}}{(\mathrm{Nx}+\mathrm{Ny}+\mathrm{Nz})}
\end{aligned}
$$

SDcomb $=$ Global standard deviation

$\mathrm{N}=$ number of cases (implants)

$\operatorname{SD}(x, y, z)=$ Standard deviation in $x, y, z$ planes

Formulas adapted from Tahmaseb and others [23].

\section{Quality assessment:}

Article bias was assessed using the Cochrane method evaluating the: random sequence generation, allocation concealment, defined inclusion / exclusion, blinding of participants and / or personnel, blinding of outcome assessment, incomplete outcome data, selective reporting. The evaluation was conducted by two researchers independently of each other and disagreements were resolved during the discussion. (Table 1) 


\section{Statistical analysis:}

The statistical analysis was conducted using Comprehensive Meta Analysis ((CMA) [computer program]. Version 3.0. Englewood, USA, Biostat, 2017). Heterogeneity of the research was assessed using Cochrane's $Q$ and $I 2$ tests. The $I 2$ test values were interpreted according to Higgins et al. [24], respectively: $>25 \%=$ slight heterogeneity, $>50 \%=$ moderate heterogeneity, $>75 \%=$ significant heterogeneity. Separate meta-analyses were performed by subdividing the data by type of deviation (angular, linear deviations of depth, apex and collar). A metaanalysis was conducted using the $Z$ test according to the Inverse Variance Weighted Random Effects Model. A meta-regression between different subgroups was conducted using the $\chi 2$ (Chi-Square) test. The data was divided into the following subgroups:

Jaws: upper, lower.

Methods of guided implantation: open, closed.

Implant insertion method: with guide, without guide.

- Type of guide support tissue: mucosa, teeth, bone.

Guide fixation: fixed, non-fixed.

The significance level of the statistical analysis was $\mathrm{P}<0.05$. The confidence intervals are $95 \%(95 \%$ C.I.) and the effect sizes are presented in the Forest plot graphs.

\section{Results}

\section{Selection of articles}

During the systematic search of scientific articles, 2102 results were found. Excluding 1902 off-topic articles, 200 article abstracts were read. 59 abstracts met the selection criteria, of which 19 articles were included in the meta-analysis (Figure 2) [25-43].

Vercruyssen and others studied the same population in two separate studies [35,38], however they measured different deviations: linear deviation of the collar and apex of the implant, angular deviation of the implant axis [35], and deviation of the implant placement depth [38]. Both articles were included in the meta-analysis.

\section{Linear deviation of implant collar}

17 studies out of 19 reported linear deviation of the implant collar. A total of 1806 implant collar deviations were analyzed. The mean implant collar deviation was $1.25 \mathrm{~mm}(95 \%$ confidence interval $(\mathrm{Cl})$ range: $1.00 \mathrm{~mm}, 1.51 \mathrm{~mm})$. The mean collar deviation between different studies ranged from $0.68 \mathrm{~mm}(95 \% \mathrm{Cl}: 0.63,0.73)$ [43] to $1.96 \mathrm{~mm}(95 \% \mathrm{Cl}: 1.92,2.00)$ [39]. The maximum recorded deviation of an individual implant colar was $7.82 \mathrm{~mm}[39]$. The results obtained were significantly heterogeneous $(12=99.34, p<0.01)$ (Fig. 3). When dividing the study subgroups according to the implantation technique it became apparent that the open implantation technique $(1.17 \mathrm{~mm}$ $(95 \% \mathrm{Cl}: 0.77,1.58))$ is more accurate than the flapless technique $(1.28 \mathrm{~mm}(95 \% \mathrm{Cl}: 0.98,1.58))$, but this result is not statistically significant $(\mathrm{p}=0.631)$ (Fig. 4). Using a surgical guide results in a $1.27 \mathrm{~mm}$ deviation $(95 \% \mathrm{Cl}: 1.03,1.52)$, while implanting without a guide yields a deviation of $1.42 \mathrm{~mm}(95 \% \mathrm{Cl}: 1.22,1.62)$, this difference is not statistically significant $(p=0.464)$ (Figure 5$)$. In the lower jaw, the deviation of the implant collars is $1.18 \mathrm{~mm}(95 \% \mathrm{Cl}: 0.85,1.51)$ in the upper jaw it is $1.43 \mathrm{~mm}(95 \% \mathrm{Cl}: 1.07,1.79)$, the difference is not statistically significant $(p=0.337)$ (Fig. 6). Using teeth as surgical guide support tissue results in a slightly larger implant collar deviation $(1.41 \mathrm{~mm}(95 \% \mathrm{Cl}: 1.09,1.73))$ compared to the mucosa $(1.27 \mathrm{~mm} \mathrm{(95 \%} \mathrm{Cl:} 0.95,1.59))$ and bone $(1.21(95 \%) \mathrm{Cl}: 0.63,1.78))$ (Figure 7$)$. The differences are not statistically significant $(p=0.892)$. If a fixed guide is used during implantation, an implant collar deviation of $1.19 \mathrm{~mm}$ $(95 \% \mathrm{Cl}: 0.98,1.40)$ is obtained, while using a non-fixed surgical guide the resulting deviation is $1.47 \mathrm{~mm}(95 \% \mathrm{Cl}: 1.33,1.62),(p=0.106)$ (Fig. 8).

\section{Linear deviation of implant apex}

14 studies reported linear deviation of the implant apex. A total of 1533 implant apex deviations were analysed. The mean deviation of the implant apex was $1.52 \mathrm{~mm}(95 \% \mathrm{Cl}: 1.18,1.86)$. The mean apex deviation between different studies ranged from $0.77 \mathrm{~mm}(95 \% \mathrm{Cl}: 0.66$, $0.88)$ [33] to $2.29 \mathrm{~mm}(95 \% \mathrm{Cl}: 2.25,2.33)$ [39]. The maximum recorded apex deviation of an individual implant was $8.73 \mathrm{~mm}$ [39]. The results were significantly heterogeneous $(12=99.41, \mathrm{p}<0.01)$ (Fig. 9). Open implant placement results in a smaller implant apex deviation $(1.36 \mathrm{~mm}(95 \% \mathrm{Cl}: 0.86,1.86))$ compared to the flapless technique $(1.56 \mathrm{~mm}(95 \% \mathrm{Cl}: 1.14,1.97)),(p=0.506)($ Fig. 10). Guided implant 
placement results in a $1.55 \mathrm{~mm}$ deviation $(95 \% \mathrm{Cl}: 1.22,1.88)$, while freehand implant placement results in a deviation of $1.69 \mathrm{~mm}(95 \% \mathrm{Cl}$ : $1.53,1.84)$, ( $p=0.631)$ (Fig. 11). Lower mandibular implants have a lower apex error (1.31 mm (95\% Cl: 0.80, 1.81)) compared to upper mandibular implants $(1.71 \mathrm{~mm}(95 \% \mathrm{Cl}: 1.19,2.23)),(\mathrm{p}=0.298)$ (Fig. 12). In regards to surgical guides by type of support, the lowest implant apex error is obtained with the alveolar bone $(1.30 \mathrm{~mm}(95 \% \mathrm{Cl}: 0.70,1.90))$, the highest error is obtained with dental support $(1.82 \mathrm{~mm}(95 \% \mathrm{Cl}: 1.45,2.19))$, while placing the guide on the mucosa results in a deviation of $1.53 \mathrm{~mm}(95 \% \mathrm{Cl}$ : 1.10, 1.96) (Figure 13$)$. There is no statistically significant difference between the above mentioned guide support groups $(p=0.626)$. A fixed surgical guide yields a statistically significant smaller implant apex deviation $(1.39 \mathrm{~mm}(95 \% \mathrm{Cl}: 1.08,1.69))$ compared to a non-fixed surgical guide (1.85mm (95\% Cl: 1.62, 2.09mm), ( $p=0.035)$ (Figure 14).

\section{Angular deviation of implant axis}

16 studies reported angular deviation of implant axes. The angular deviations of 1821 implant axes were analysed in general. The mean angular deviation of the implant axis was $3.47 \mathrm{o}(95 \% \mathrm{Cl}$ : 3.01, 3.94). The mean angular axis deviation between different studies ranged from 1.89 o (95\% Cl: 1.76, 2.02) [30] to 4.89 o (95\% Cl: 4.46, 5.32) [26]. The maximum recorded angular deviation of the individual implant axis was 21.160 [26]. The results obtained were significantly heterogeneous $(I 2=98.56, p<0.01)($ Fig. 15). A slightly angular deviation (3.27o $(95 \% \mathrm{Cl}: 2.44,4.10))$ was obtained by open implant insertion compared to flapless $(3.360(95 \% \mathrm{Cl}$ : $2.83,3.89))$, (p = 0.843) (Fig. 16). Inserting the implants through a surgical guide results in a smaller angular deviation of the implant axis (3.47o (95\% Cl: 3.03, 3.92)) compared to freehand placement $(3.890(95 \% \mathrm{Cl}: 2.60,5.19)),(p=0.442)$ (Figure 17). A smaller angular deviation of the implant axis is evident when the implants are inserted in the upper jaw $(3.270(95 \% \mathrm{Cl}: 2.26,4.28))$ than in the lower one $(4.030(95 \% \mathrm{Cl}$ : $1.86,6.21))$, $(\mathrm{p}=$ 0.296) (Fig. 18). Dental surgical guide support results in the largest angular deviation of the implant (3.680 (95\% Cl: $2.32,5.04))$ and the lowest angular deviation is attained using the alveolar bone $(3.090(95 \% \mathrm{Cl}: 2.16,4.03))$. Using the mucosa for the surgical guide support gives an error of $3.340(95 \% \mathrm{Cl}: 2.80,3.88)$ (Fig. 19). These differences are not statistically significant $(p=0.815)$. The fixed surgical guide gives a smaller angular deviation of the implant axis (3.37o (95\% Cl: $2.75,3.99)$ ) compared to the non-fixed guide (4.22o (95\% Cl: 3.08 , 5.37)), ( $p=0.079)$ (Fig. 20).

\section{Linear deviation of implant insertion depth}

10 studies reported deviation of implant insertion depth. In total, the depth deviations of 950 implants were analysed. The mean implant depth deviation was $0.15 \mathrm{~mm}(95 \% \mathrm{Cl}$ : $-0.36,0.66)$. The mean depth deviation between different studies ranged from $0.93 \mathrm{~mm}(95 \% \mathrm{Cl}$ : 0.77 , 1.09) [28] to $-1.51 \mathrm{~mm}(95 \% \mathrm{Cl}:-2.14,-0.88)$ [27]. The maximum recorded depth deviation of an individual implant inserted too deeply was $4.7 \mathrm{~mm}$ [37] and the maximum deviation of an implant that was not inserted deep enough was $-4.11 \mathrm{~mm}$ [39]. The results obtained were significantly heterogeneous ( $12=99.66, \mathrm{p}<0.01)$ (Fig. 21). Using the open method the implants were inserted deeper $(0.87 \mathrm{~mm}(95 \% \mathrm{Cl}$ : $0.42,1.33))$ than using the flapless method $(0.08 \mathrm{~mm}(95 \% \mathrm{Cl}:-0.4,0.56)),(p=0.089)$ (Fig. 22). Using freehand placement, the implants were inserted deeper than using a surgical guide, $0.95 \mathrm{~mm}(95 \% \mathrm{Cl}: 0.73,1.17)$ and $0.25 \mathrm{~mm}(95 \% \mathrm{Cl}:-0.19,0.68)$, ( $p=0.098)$, respectively (Fig. 23). In the upper jaw, implants were not inserted deep enough $(-0.26 \mathrm{~mm}$ (95\% Cl: $-0.91,0.39))$, while in lower jaw they were inserted too deep $(0.38 \mathrm{~mm}(95 \% \mathrm{Cl}:-0.92,1.67))$, $(\mathrm{p}=0.291)$ (Fig. 24). When using the teeth as a surgical guide support, the implants were not inserted deep enough $(-0.27 \mathrm{~mm}(95 \% \mathrm{Cl}:-2.66,2.12))$, while using the alveolar bone, they were inserted too deep (0.87mm (95\% Cl: 0.42 , 1.33). The smallest depth error was obtained with a mucosal implanted surgical guide $(0.15 \mathrm{~mm}(95 \% \mathrm{Cl}:-0.35,0.66))(\mathrm{Fig}$. 25$)$. There was no statistically significant difference between the different surgical guide support groups $(p=0.197)$. A smaller deviation in implant depth is obtained with a non-fixed surgical guide $(0.51 \mathrm{~mm}(95 \% \mathrm{Cl}: 0.21,0.81))$ compared to a fixed surgical guide (0.65mm ( $95 \% \mathrm{Cl}$ : $0.37,0.92)$ ), $(p=0.491)$ (Fig. 26).

\section{Discussion}

The studies analyzed in this literature review showed significant heterogeneity (I2 > 98\%). Seeing as how the implantation protocols of individual studies differed, this heterogeneity was predicted prior to meta-analysis. Such heterogeneity results are observed in all metaanalyses published over the past 15 years that investigate implant accuracy using static implantation guides [3, 44-48]. According to Jung et al. [3], published in 2009, The International Team for Implantology (ITI), at the ITI Annual Conference, decided to ignore the heterogeneity of the research found in this review and to conduct a meta-analysis. During the selection of articles it was decided to not take into account the technique of computed tomography and the experience of the operating surgeons. Cone beam computed tomography (CT) was most commonly used in this study. Multi-layer and spiral computed tomography were used much less frequently. In a study conducted by Arisan and others, the accuracy of guided surgical implants was compared using cone bean and multi-layer computed tomography equipment. According to the results, there is no significant difference between these types of computed tomography. An identical conclusion was reached by Poeschl and others [49]. There is considerable inconsistency in the scientific literature

Page 6/33 
regarding the influence of the clinical experience of the implanting surgeon on the accuracy of implant insertion. Some studies mention that the implanting surgeon's experience has a significant impact on implant insertion accuracy [50-52], while other studies mention that surgeon experience is not a significant criterion for examining implant accuracy [41, 43, 53] Wiele et al. [41], found that inexperienced surgeons achieved significantly lower errors in implant collar, apex, and depth. The angular deviation was higher in the inexperienced surgeon group, but this was not a statistically significant finding. In this study, a group of inexperienced surgeons consisted of periodontologists with no guided implantation experience and limited freehand placement experience. Cassetta et al. [43], discovered the opposite in their study - the implantation errors of the inexperienced surgeons were more significant in the collar and apex areas, but angular errors were smaller compared to experienced surgeons. These results were not statistically significant.

In implantology literature, it is accepted that a $2 \mathrm{~mm}$ deviation between the planned and actual position of the implant is clinically significant due to this distance being recommended between the implant and surrounding anatomical structures [20]. The mean implant position deviations obtained in this literature review are similar to the implant position deviations obtained in previous meta-analyses [3, 44-48]. In the literature, the mean implant collar deviation in ranges from $1.0 \mathrm{~mm}$ [45] to $1.16 \mathrm{~mm}$ [47], while $1.25 \mathrm{~mm}$ was obtained in this study. The mean apex deviation ranges from $1.4 \mathrm{~mm}[44,45]$ to $1.96 \mathrm{~mm}$ [47], in this study it is $1.52 \mathrm{~mm}$ (95\% Cl: $1.18-1.86 \mathrm{~mm})$, meaning that inserting multiple implants close to one another and leaving a recommended minimum distance of $3 \mathrm{~mm}$ of implants, their apex parts may intersect. The angular deviation in the literature ranges between 3.980 [44] and 5.7o [47], in this review it is 3.47o. This angular misalignment allows the prosthesis of inaccurately inserted adjacent implants without the use of hexagonal supports or special angular support [3, 5]. Implant depth deviation was analysed by only two meta-analyses [44, 45], yielding deviations of $0.74 \mathrm{~mm}$ and $0.6 \mathrm{~mm}$ deviations. The $0.15 \mathrm{~mm}$ deviation obtained in this meta-analysis is significantly smaller than that of previous meta-analyzes. This result can be explained by the fact that in both studies $[44,45]$, the authors gave the vertical deviations of implant position only positive values, regardless of whether the implants were inserted too deep or not deep enough. In this study, the deviation of implants that are not deep enough is given a negative value, which results in a lower mean depth deviation when summarizing the results of several studies. The average implant depth deviation obtained in this meta-analysis is within the safe distance to adjacent anatomical structures, so implantation near important anatomical structures (maxillary sinus, inferior alveolar nerve) is safe. In most older meta-analyzes, implantation results obtained in in vivo, ex vivo, and in vitro studies were grouped together [44-47], which makes it difficult to compare subgroup analysis results from previous meta-analyses. The influence of surgical methods on implant deviations was not analyzed in any of the reviews. The results of this review make it apparent that the open surgical implantation method result in smaller implant position deviations compared to the flapless method, but this difference is not statistically significant. The open implantation method has drawbacks: due to the rupture of the cervix, resorption results in the loss of a small amount of the alveolar bone and can result in gum recession, postoperative swelling, discomfort and potential hematomas [54]. Dental implantation techniques are characterized by less postoperative discomfort, swelling and less frequent hematomas, while gum recessions do not develop as long as the bone is not damaged [53]. Currently, there is a lack of data in scientific literature on the influence of surgical methods on implant position deviations. The increased number of clinical trials conducted under standardized conditions would allow the formulation of specific guidelines for clinical practice. Meta-analyzes by Ramos et al. [44], and Asche et al. [45], also suggest that implant insertion through a surgical guide results in smaller implant position deviations compared to freehand implant placement. According to Asche et al. [45], a fixed surgical guide reduced implant position deviations more than a freely held surgical guide. The results of this meta-analysis regarding the type of surgical guide support do not coincide with those of previous reviews $[45,46,48]$. According to these reviews, surgical guides that are fixed on the teeth have the smallest deviations of the implant position, while guides fixed on the alveolar bone have the largest deviations. The results obtained in this meta-analysis are the opposite: the smallest deviations of the implant position are observed in the alveolar bone area, and the largest is recorded when the guide is fixed on the adjacent teeth (Tables 2-4). This result may have been distorted by the extremely small number of scientific articles and research subgroups that have used guides fixed on the alveolar bone and teeth [27, 33, $35,38,42]$.

This literature review did not include studies using freehand implant placement methods. The main reason for this exclusion was the lack of scientific literature and the heterogeneity of the methods used in articles. The systematic search has yielded 9 publications measuring the accuracy of freehand placement implants $[35,38,55-61]$. The methodology of all publications varied greatly. In 3 studies, the accuracy of implants was tested ex vivo [55-57], one of them, that of Sherer and others [58], investigated the accuracy in porcine jaws. The other two studies investigated the accuracy of implants in human jaws ex vivo. 4 studies investigated the accuracy of freehand implant placement in vitro [58-61]. In all of the above studies, implantation accuracy was measured by different methods. Nickenig et al. [58], used cone beam computed tomography before and after implant insertion, Park SJ scanned jaw patterns after implant insertion using a threedimensional scanner, and Park C. et al measured postoperative implant positions using a coordinate measuring device. Two studies measured implant position deviations on humans, in vivo conditions, comparing implantation with surgical guides to non-surgical guides $[35,38]$. Both studies looked at the same population and measured different implant position deviations. When using the freehand 
placement method, the mean collar deviation of the implant was $2.7 \mathrm{~mm}$ (ranged 0.3-8.3 mm), whereas in identical conditions using a surgical guide, the implant collar deviation was $1.38 \mathrm{~mm}$. The apex deviation was $2.9 \mathrm{~mm}$ (ranged $0.5-7.4 \mathrm{~mm}$ ), using a guide $-1.58 \mathrm{~mm}$. The angular deviation was 9.9o (ranged 1.5o-27.8o), using a guide - 3.14o [35], implant depth deviation was $1.7 \pm 1.3 \mathrm{~mm}$ (ranged 0.0$6.4 \mathrm{~mm}$ ), using a guide $-0.9 \mathrm{~mm}$ [38]. The results obtained in all studies show that implantation without a surgical guide results in significantly larger implant position deviations compared to implantation with a static surgical guide $[35,38,56-60]$. These results describe ex vivo, in vitro and in vivo studies.

\section{Conclusion}

The surgical technique, implant insertion method, jaw, guide supporting tissue and fixation has an effect on the deviation of inserted implants. Due to deviations in the position of implants during guided implantation, it is recommended to use fixed surgical guides and open implantation. These methods increase the accuracy of implantation and are safer than freehand placement. More clinical trials are needed to research the impact of implantation methods on implant deviation to obtain greater statistical significance.

\section{Declarations}

Ethics approval and consent to participate: Not applicable.

Consent for publication: Not applicable.

Availability of data and materials: All data generated and analyzed in this review are included within the article.

Competing interests: The authors declare that they have no competing interests with regards to authorship and/or publication of this paper.

Funding: Not applicable

Author contributions: All authors have contributed equaly. All authors have read and approved the manuscript.

Acknowledgements: Not applicable

\section{References}

1. Orentlicher G, Abboud M. Guided surgery for implant therapy. Oral Maxillofac Surg Clin North Am. 2011 May;23(2):239-56. v-vi.

2. Beretta M, Poli PP, Maiorana C. Accuracy of computer-aided template-guided oral implant placement: a prospective clinical study. Journal of Periodontal Implant Science. 2014;44(4):184-93.

3. Jung RE, Schneider D, Ganeles J, Wismeijer D, Zwahlen M, Hämmerle CH, Tahmaseb A. Computer technology applications in surgical implant dentistry: A systematic review. Int J Oral Maxillofac Implants. 2009;24(suppl):92-109.

4. Van assche N, Vercruyssen M, Coucke W, Teughels W, Jacobs R, Quirynen M. Accuracy of computer-aided implant placement. Clin Oral Implants Res. 2012;23 Suppl 6:112 - 23.

5. Vercruyssen M, Hultin M, Van assche N, Svensson K, Naert I, Quirynen M. Guided surgery: accuracy and efficacy. Periodontol 2000. 2014;66(1):228-46.

6. Arisan V, Karabuda ZC, Pişkin B, Ozdemir T. Conventional multi-slice computed tomography (CT) and cone-beam CT (CBCT) for computer-aided implant placement. part II: reliability of mucosa-supported stereolithographic guides. Clin Implant Dent Relat Res. 2013;15(6):907-17. 
7. Poeschl PW, Schmidt N, Guevara-Rojas G, Seeman R, Ewers R, Zipko HT, Schicho K. Comparison of cone-beam and conventional multislice computed tomography for image guided dental implant planning. Clin Oral Investig. 2013;17(1):317-24.

8. Vercruyssen M, Jacobs R, Van assche N, Van steenberghe D. The use of CT scan based planning for oral rehabilitation by means of implants and its transfer to the surgical field: a critical review on accuracy. J Oral Rehabil. 2008;35(6):454-74.

9. Van steenberghe D, Glauser R, Blombäck U. A computed tomographic scan-derived customized surgical template and fixed prosthesis for flapless surgery and immediate loading of implants in fully edentulous maxillae: a prospective multicenter study. Clin Implant Dent Relat Res. 2005;7(Suppl 1):111-20.

10. Dreiseidler T, Neugebauer J, Ritter L, Lingohr T, Rothamel D, Mischkowski RA, Zoller JE. Accuracy of a newly developed integrated system for dental implant planning. Clin Oral Implants Res. 2009;20(11):1191-9.

11. D'haese J, Van De Velde T, Elaut L, De Bruyn H. A prospective study on the accuracy of mucosally supported stereolithographic surgical guides in fully edentulous maxillae. Clin Implant Dent Relat Res. 2012;14(2):293-303.

12. Arisan V, Karabuda CZ, Ozdemir T. Implant surgery using bone- and mucosa-supported stereolithographic guides in totally edentulous jaws: surgical and post-operative outcomes of computer-aided vs. standard techniques. Clin Oral Implants Res. 2010;21(9):980-8.

13. Al Harbi SA, Sun AY. Implant placement accuracy when using stereolithographic template as a surgical guide: preliminary results. Implant Dent. 2009;18(1):46-56.

14. Van assche N, Quirynen M. Tolerance within a surgical guide. Clin Oral Implants Res. 2010;21(4):455-8.

15. Vasak C, Watzak G, Gahleitner A, Strbac G, Schemper M, Zechner W. Computed tomography- based evaluation of template (NobelGuide)-guided implant positions: a prospective radiological study. Clin Oral Implants Res. 2011;22(10):1157-63.

16. D'haese J, De Bruyn H. Effect of smoking habits on accuracy of implant placement using mucosally supported stereolithographic surgical guides. Clin Implant Dent Relat Res. 2013;15(3):402-11.

17. Rousseau P. Flapless and traditional dental implant surgery: an open, retrospective comparative study. J Oral Maxillofac Surg. 2010;68:2299-306.

18. Accuracy and complications using computer-designed stereolithographic surgical guides for oral rehabilitation by means of D'haese J, Van De Velde T, Komiyama A, Hultin M, De Bruyn H. Accuracy and complications using computer-designed stereolithographic surgical guides for oral rehabilitation by means of. dental implants. a review of the literature. Clin Implant Dent Relat Res. 2012;14:321-35.

19. A systematic review on the accuracy and the Schneider $D$, Marquardt $P$, Zwahlen $M$, Jung RE. A systematic review on the accuracy and the.

clinical outcome of computer-guided template-based implant dentistry. Clin Oral Impl Res. 2009;20(Suppl. 4):73-86.

20. Vieira DM, Sotto-Maior BS, Barros CA, Reis ES, Francischone CE. Clinical accuracy of flapless computer-guided surgery for implant placement in edentulous arches. Int J Oral Maxillofac Implants. 2013;28(5):1347-51.

21. Moher D, Liberati A, Tetzlaff J, Altman DG. Preferred reporting items for systematic reviews and meta-analyses: The PRISMA statement. Int J Surg. 2010 Feb;8(5):336-41.

22. Chien PF, Khan KS, Siassakos D. Registration of systematic reviews: PROSPERO. BJOG. 2012 Jul;119(8):903-5.

23. Tahmaseb A, Wismeijer D, Coucke W, Derksen W. Computer Technology Applications in Surgical Implant Dentistry: A Systematic Review. Int J Oral Maxillofac Implants. 2014;29(suppl):25-42.

24. Higgins JP, Thompson SG, Deeks JJ, Altman DG. Measuring inconsistency in meta-analyses. BMJ. 2003;327(7414):557-60.

25. Arisan V, Karabuda ZC, Pişkin B, Özdemir T. Conventional multi-slice computed tomography (CT) and cone-beam CT (CBCT) for computer-aided implant placement. Part II: reliability of mucosa-supported stereolithographic guides. Clin Implant Dent Relat Res. 2013;15(6):907-17.

26. Cassetta M, Giansanti M, Di Mambro A, Calasso S, Barbato E. Accuracy of two stereolithographic surgical templates: a retrospective study. Clin Implant Dent Relat Res. 2013;15(3):448-59.

27. Farley NE, Kennedy K, McGlumphy EA, Clelland NL. Split-mouth comparison of the accuracy of computer-generated and conventional surgical guides. Int J Oral Maxillofac Implants. 2013;28(2):563-72.

28. Lee JH, Park JM, Kim SM, Kim MJ, Lee JH, Kim MJ. An assessment of template-guided implant surgery in terms of accuracy and related factors. J Adv Prosthodont. 2013 Nov;5(4):440-7.

29. Ochi M, Kanazawa M, Sato D, Kasugai S, Hirano S, Minakuchi S. Factors affecting accuracy of implant placement with mucosasupported stereolithographic surgical guides in edentulous mandibles. Comput Biol Med. 2013;43(11):1653-60.

Page 9/33 
30. Vieira DM, Sotto-Maior BS, Barros CA, Reis ES, Francischone CE. Clinical accuracy of flapless computer-guided surgery for implant placement in edentulous arches. Int J Oral Maxillofac Implants. 2013;28(5):1347-51.

31. Cassetta M, Giansanti M, Di Mambro A, Stefanelli LV. Accuracy of positioning of implants inserted using a mucosa-supported stereolithographic surgical guide in the edentulous maxilla and mandible. Int J Oral Maxillofac Implants. 2014;29(5):1071-8.

32. Cassetta M, Di Mambro A, Giansanti M, Stefanelli LV, Barbato E. How does an error in positioning the template affect the accuracy of implants inserted using a single fixed mucosa-supported stereolithographic surgical guide? Int J Oral Maxillofac Surg. 2014;43(1):8592.

33. Stübinger S, Buitrago-Tellez C, Cantelmi G. Deviations between placed and planned implant positions: an accuracy pilot study of skeletally supported stereolithographic surgical templates. Clin Implant Dent Relat Res. 2014;16(4):540-51.

34. Testori T, Robiony M, Parenti A, Luongo G, Rosenfeld AL, Ganz SD, Mandelaris GA, Del Fabbro M. Evaluation of accuracy and precision of a new guided surgery system: a multicenter clinical study. Int J Periodontics Restorative Dent. 2014;34(Suppl 3):59-69.

35. Vercruyssen M, Cox C, Coucke W, Naert I, Jacobs R, Quirynen M. A randomized clinical trial comparing guided implant surgery (boneor mucosa-supported) with mental navigation or the use of a pilot-drill template. J Clin Periodontol. 2014;41(7):717-23.

36. Cassetta M, Di Mambro A, Di Giorgio G, Stefanelli LV, Barbato E. The Influence of the Tolerance between Mechanical Components on the Accuracy of Implants Inserted with a Stereolithographic Surgical Guide: A Retrospective Clinical Study. Clin Implant Dent Relat Res. 2015;17(3):580-8.

37. Sun Y, Luebbers HT, Agbaje JO, Schepers S, Politis C, Van Slycke S, Vrielinck L. Accuracy of Dental Implant Placement Using CBCTDerived Mucosa-Supported Stereolithographic Template. Clin Implant Dent Relat Res. 2015;17(5):862-70.

38. Vercruyssen M, Coucke W, Naert I, Jacobs R, Teughels W, Quirynen M. Depth and lateral deviations in guided implant surgery: an RCT comparing guided surgery with mental navigation or the use of a pilot-drill template. Clin Oral Implants Res. 2015;26(11):1315-20.

39. Verhamme LM, Meijer GJ, Bergé SJ, Soehardi RA, Xi T, de Haan AF, Schutyser F, Maal TJ. An Accuracy Study of Computer-Planned Implant Placement in the Augmented Maxilla Using Mucosa-Supported Surgical Templates. Clin Implant Dent Relat Res. 2015;17(6):1154-63.

40. Verhamme LM, Meijer GJ, Boumans T, de Haan AF, Bergé SJ, Maal TJ. A clinically relevant accuracy study of computer-planned implant placement in the edentulous maxilla using mucosa-supported surgical templates. Clin Implant Dent Relat Res. 2015;17(2):343-52.

41. Van de Wiele G, Teughels W, Vercruyssen M, Coucke W, Temmerman A, Quirynen M. The accuracy of guided surgery via mucosasupported stereolithographic surgical templates in the hands of surgeons with little experience. Clin Oral Implants Res. 2015;26(12):1489-94.

42. Lee DH, An SY, Hong MH, Jeon KB, Lee KB. Accuracy of a direct drill-guiding system with minimal tolerance of surgical instruments used for implant surgery: a prospective clinical study. J Adv Prosthodont. 2016;8(3):207-13.

43. Cassetta M, Bellardini M. How much does experience in guided implant surgery play a role in accuracy? A randomized controlled pilot study. Int J Oral Maxillofac Surg. 2017;46(7):922-30. 12.

44. Bover-Ramos F, Viña-Almunia J, Cervera-Ballester J, Peñarrocha-Diago M, García-Mira B. Accuracy of Implant Placement with Computer-Guided Surgery: A Systematic Review and Meta-Analysis Comparing Cadaver, Clinical, and In Vitro Studies. Int J Oral Maxillofac Implants. 2017. 6.

45. Van Assche N, Vercruyssen M, Coucke W, Teughels W, Jacobs R, Quirynen M. Accuracy of computer-aided implant placement. Clin Oral Impl Res. 2012;23(Suppl. 6):112-23.

46. Tahmaseb A, Wismeijer D, Coucke W, Derksen W. Computer Technology Applications in Surgical Implant Dentistry: A Systematic Review. Int J Oral Maxillofac Implants. 2014;29(suppl):25-42.

47. Schneider D, Marquardt P, Zwahlen M, Jung RE. A systematic review on the accuracy and the clinical outcome of computer-guided template-based implant dentistry. Clin Oral Impl Res. 2009;20(Suppl.4):73-86.

48. Raico Gallardo YN, Rodrigues Teixeirada da Silva-Olivio I, Mukai E, Morimoto S, Sesma N, Cordaro L. Accuracy comparison of guided surgery for dental implants according to the tissue of support: a systematic review and meta-analysis. Clin. Oral Impl. Res. 2017;28(5):602-612.

49. Poeschl PW, Schmidt N, Guevara-Rojas G, Seeman R, Ewers R, Zipko HT, Schicho K. Comparison of cone-beam and conventional multislice computed tomography for image guided dental implant planning. Clin Oral Investig. 2013;17(1):317-24.

50. Cassetta M, Stefanelli LV, Giansanti M, Di mambro A, Calasso S. Depth deviation and occurrence of early surgical complications or unexpected events using a single stereolithographic surgi-guide. Int J Oral Maxillofac Surg. 2011;40(12):1377-87.

Page $10 / 33$ 
51. Sicilia A, Botticelli D. Computer-guided implant therapy and soft- and hard-tissue aspects. The Third EAO Consensus Conference 2012. Clin Oral Implants Res. 2012;23 Suppl 6:157 - 61.

52. Cushen SE, Turkyilmaz I. Impact of operator experience on the accuracy of implant placement with stereolithographic surgical templates: an in vitro study. J Prosthet Dent. 2013;109(4):248-54.

53. Valente F, Schiroli G, Sbrenna A. Accuracy of computer-aided oral implant surgery: a clinical and radiographic study. Int J Oral Maxillofac Implants. 2009;24(2):234-42.

54. Wood DL, Hoag PM, Donnenfeld OW, Rosenfeld LD. Alveolar crest reduction following full and partial thickness flaps. J Periodontol. 1972;43:141-4.

55. Rousseau P. Flapless and traditional dental implant surgery: an open, retrospective comparative study. J Oral Maxillofac Surg. 2010;68:2299-306.

56. Gillot L, Cannas B, Friberg B, Vrielinck L, Rohner D, Pettersson A. Accuracy of virtually planned and conventionally placed implants in edentulous cadaver maxillae and mandibles: a preliminary report. J Prosthet Dent. 2014;112(4):798-804.

57. Scherer U, Stoetzer M, Ruecker M, Gellrich NC. Von see C. Template-guided vs. non-guided drilling in site preparation of dental implants. Clin Oral Investig. 2015;19(6):1339-46.

58. Noharet R, Pettersson A, Bourgeois D. Accuracy of implant placement in the posterior maxilla as related to 2 types of surgical guides: a pilot study in the human cadaver. J Prosthet Dent. 2014;112(3):526-32.

59. Nickenig HJ, Wichmann M, Hamel J, Schlegel KA, Eitner S. Evaluation of the difference in accuracy between implant placement by virtual planning data and surgical guide templates versus the conventional free-hand method - a combined in vivo - in vitro technique using cone- beam CT (Part II). J Craniomaxillofac Surg. 2010;38(7):488-93.

60. Park C, Raigrodski AJ, Rosen J, Spiekerman C, London RM. Accuracy of implant placement using precision surgical guides with varying occlusogingival heights: an in vitro study. J Prosthet Dent. 2009;101(6):372-81.

61. Park SJ, Leesungbok R, Cui T, Lee SW, Ahn SJ. Reliability of a CAD/CAM Surgical Guide for Implant Placement: An In Vitro Comparison of Surgeons' Experience Levels and Implant Sites. Int J Prosthodont. 2017;30(4):367-169.

\section{Tables}

Tab. 1. Assessment of the risk of bias 


\begin{tabular}{|c|c|c|c|c|c|c|c|}
\hline & $\begin{array}{l}\text { Random sequence } \\
\text { generation }\end{array}$ & $\begin{array}{l}\text { Allocation } \\
\text { concealment }\end{array}$ & $\begin{array}{l}\text { Defined } \\
\text { inclusion/exclusion }\end{array}$ & $\begin{array}{l}\text { Blinding of participants and/or } \\
\text { personnel }\end{array}$ & $\begin{array}{l}\text { Blinding of outcome } \\
\text { assessment }\end{array}$ & $\begin{array}{l}\text { Incomplete } \\
\text { outcome data }\end{array}$ & $\begin{array}{l}\text { Selective } \\
\text { reporting }\end{array}$ \\
\hline Arisan et al $2013^{25}$ & - & + & + & + & - & + & + \\
\hline $\begin{array}{l}\text { Cassetta et al } \\
2013^{26}\end{array}$ & - & - & + & N/A & $\mathrm{N} / \mathrm{A}$ & + & + \\
\hline Farley et al $2013^{27}$ & - & + & + & N/A & N/A & + & + \\
\hline Lee et al $2013^{28}$ & - & $\mathrm{N} / \mathrm{A}$ & + & N/A & $\mathrm{N} / \mathrm{A}$ & + & + \\
\hline Ochi et al $2013^{29}$ & - & $\mathrm{N} / \mathrm{A}$ & + & N/A & $\mathrm{N} / \mathrm{A}$ & + & + \\
\hline Vieira et al $2013^{30}$ & - & N/A & + & N/A & $\mathrm{N} / \mathrm{A}$ & + & + \\
\hline $\begin{array}{l}\text { Cassetta et al } \\
2014^{31}\end{array}$ & - & $\mathrm{N} / \mathrm{A}$ & + & N/A & $\mathrm{N} / \mathrm{A}$ & + & + \\
\hline $\begin{array}{l}\text { Cassetta et al } \\
2014^{32}\end{array}$ & - & N/A & + & N/A & $\mathrm{N} / \mathrm{A}$ & + & + \\
\hline $\begin{array}{l}\text { Stübinger et al } \\
2014^{33}\end{array}$ & - & $\mathrm{N} / \mathrm{A}$ & + & N/A & $\mathrm{N} / \mathrm{A}$ & + & + \\
\hline $\begin{array}{l}\text { Testori et al } \\
2014^{34}\end{array}$ & - & N/A & + & N/A & $\mathrm{N} / \mathrm{A}$ & + & + \\
\hline $\begin{array}{l}\text { Vercruyssen et al } \\
2014^{35}\end{array}$ & N/A & N/A & + & N/A & $\mathrm{N} / \mathrm{A}$ & + & + \\
\hline $\begin{array}{l}\text { Cassetta et al } \\
2015^{36}\end{array}$ & - & - & - & - & $\mathrm{N} / \mathrm{A}$ & + & + \\
\hline Sun et al $2015^{37}$ & - & $\mathrm{N} / \mathrm{A}$ & - & N/A & $\mathrm{N} / \mathrm{A}$ & + & + \\
\hline $\begin{array}{l}\text { Vercruyssen et } \\
\mathrm{al}^{38} 2015\end{array}$ & - & + & - & - & $\mathrm{N} / \mathrm{A}$ & + & + \\
\hline $\begin{array}{l}\text { Verhamme et al } \\
2015^{39}\end{array}$ & - & $\mathrm{N} / \mathrm{A}$ & $\mathrm{N} / \mathrm{A}$ & N/A & $\mathrm{N} / \mathrm{A}$ & + & + \\
\hline $\begin{array}{l}\text { Verhamme et al } \\
2015^{40}\end{array}$ & - & N/A & + & $\mathrm{N} / \mathrm{A}$ & $\mathrm{N} / \mathrm{A}$ & + & + \\
\hline $\begin{array}{l}\text { Van de Wiele et al } \\
2015^{41}\end{array}$ & - & $\mathrm{N} / \mathrm{A}$ & + & N/A & $\mathrm{N} / \mathrm{A}$ & + & + \\
\hline Lee et al $2016^{42}$ & - & $\mathrm{N} / \mathrm{A}$ & $\mathrm{N} / \mathrm{A}$ & N/A & $\mathrm{N} / \mathrm{A}$ & + & + \\
\hline $\begin{array}{l}\text { Cassetta et al } \\
2017^{43}\end{array}$ & - & + & + & + & + & + & + \\
\hline
\end{tabular}

+low risk; N/A - unclear risk; - high risk.

Tab. 2. Data characteristics of included studies. 


\begin{tabular}{|c|c|c|c|c|c|c|c|c|c|c|c|c|c|c|c|c|}
\hline $\begin{array}{l}\text { Study, } \\
\text { subgroup }\end{array}$ & $\begin{array}{c}\text { Implant } \\
\text { planning } \\
\text { system }\end{array}$ & $\begin{array}{c}\text { Number } \\
\text { of } \\
\text { patients }\end{array}$ & $\begin{array}{c}\text { Number } \\
\text { of } \\
\text { implants }\end{array}$ & $\begin{array}{r}\text { Method of } \\
\text { surgery }\end{array}$ & $\begin{array}{l}\text { Implant } \\
\text { insertion } \\
\text { method }\end{array}$ & Jaw & $\begin{array}{l}\text { Guide } \\
\text { fixation } \\
\text { method }\end{array}$ & $\begin{array}{r}\text { Guide } \\
\text { fixation }\end{array}$ & $\begin{array}{c}\text { Implant } \\
\text { collar } \\
\text { deviation } \\
(\mathrm{mm}) \pm \mathrm{SD}\end{array}$ & $\begin{array}{l}\text { Max. } \\
(\mathrm{mm})\end{array}$ & $\begin{array}{c}\text { Implant } \\
\text { apex } \\
\text { deviation } \\
(\mathrm{mm})[\mathrm{SD}]\end{array}$ & $\begin{array}{l}\text { Max. } \\
(\mathrm{mm})\end{array}$ & $\begin{array}{c}\text { Implant } \\
\text { axis } \\
\text { deviation } \\
\text { (degree) } \\
\text { [SD] }\end{array}$ & $\begin{array}{c}\text { Max } \\
\text { (degree) }\end{array}$ & $\begin{array}{c}\text { Depth } \\
\text { deviation } \\
(\mathrm{mm}) \\
{[\mathrm{SD}]}\end{array}$ & $\begin{array}{l}\text { Max. } \\
\text { (mm) }\end{array}$ \\
\hline $\begin{array}{c}\text { Arisan et al. } \\
2013^{25}\end{array}$ & Simplant & 11 & 102 & Flapless & $\begin{array}{c}\text { Fully } \\
\text { guided }\end{array}$ & Both & Mucosa & Fixed & $0.78 \pm 0.32$ & 1.31 & $0.84 \pm 0.33$ & 1.34 & $3.39 \pm 1.12$ & 5.12 & - & - \\
\hline a & & & 52 & & & Both & & & $0.81 \pm 0.32$ & 1.31 & $0.87 \pm 0.32$ & 1.33 & $3.47 \pm 1.14$ & 5.12 & & \\
\hline $\mathrm{b}$ & & & 23 & & & Maxilla & & & $0.82 \pm 0.33$ & 1.31 & $0.88 \pm 0.32$ & 1.3 & & - & & \\
\hline c & & - & 29 & & & Mandible & & & $0.8 \pm 0.34$ & 1.29 & $0.89 \pm 0.34$ & 1.32 & & - & & \\
\hline $\mathrm{d}$ & & & 50 & & & Both & & & $0.75 \pm 0.32$ & 1.26 & $0.8 \pm 0.35$ & 1.34 & $3.3 \pm 1.09$ & 4.98 & & \\
\hline e & & & 26 & & & Maxilla & & & $0.73 \pm 0.33$ & 1.26 & $0.81 \pm . .36$ & 1.34 & & - & & \\
\hline $\mathrm{f}$ & & & 24 & & & Mandible & & & $0.74 \pm 0.3$ & 1.12 & $0.77 \pm 0.35$ & 1.31 & & - & & \\
\hline $\begin{array}{c}\text { Cassetta et } \\
\text { al. } \\
2013^{26}\end{array}$ & Simplant & 20 & 227 & Flapless/Open & $\begin{array}{l}\text { Fully } \\
\text { guided/ } \\
\text { Half } \\
\text { guided }\end{array}$ & Both & $\begin{array}{c}\text { Bone/ } \\
\text { Mucosa/ } \\
\text { Teeth }\end{array}$ & $\begin{array}{l}\text { Fixed/ } \\
\text { Non- } \\
\text { fixed }\end{array}$ & $1.49 \pm 0.65$ & 3.88 & $1.9 \pm 0.95$ & 6.41 & $4.89 \pm 3.33$ & 21.16 & $\begin{array}{c}0.86 \\
\pm 0.63\end{array}$ & 3.53 \\
\hline $\mathrm{a}$ & & 10 & 116 & & $\begin{array}{c}\text { Half } \\
\text { guided }\end{array}$ & & & $\begin{array}{l}\text { Non- } \\
\text { fixed }\end{array}$ & $1.47 \pm 0.68$ & 3.88 & $1.83 \pm 1.03$ & 6.41 & $5.09 \pm 3.7$ & 21.16 & $\begin{array}{c}0.98 \\
\pm 0.71\end{array}$ & 3.53 \\
\hline $\mathrm{b}$ & & - & 57 & & $\begin{array}{l}\text { Fully } \\
\text { guided }\end{array}$ & & & Fixed & $1.49 \pm 0.63$ & 3 & $1.9 \pm 0.83$ & 3.98 & $3.93 \pm 2.34$ & 14.34 & $\begin{array}{c}0.85 \\
\pm 0.63\end{array}$ & 2.29 \\
\hline $\mathrm{C}$ & & & 54 & & & & & $\begin{array}{l}\text { Non- } \\
\text { fixed }\end{array}$ & $1.55 \pm 0.59$ & 2.79 & $2.05 \pm 0.89$ & 4.23 & $5.46 \pm 3.38$ & 15.25 & $\begin{array}{c}0.63 \\
\pm 0.43 \\
\end{array}$ & 1.58 \\
\hline $\begin{array}{c}\text { Farley et } \\
\text { al. } \\
2013^{27} \\
\end{array}$ & $\begin{array}{l}\text { Implant } \\
\text { Master }\end{array}$ & 10 & 10 & Flapless & $\begin{array}{l}\text { Fully } \\
\text { guided }\end{array}$ & Both & Teeth & $\begin{array}{l}\text { Non- } \\
\text { fixed }\end{array}$ & $1.45 \pm 0.6$ & 2.67 & $1.82 \pm 0.3$ & 2.69 & $3.68 \pm 2.19$ & 7.98 & $\begin{array}{l}-1.51 \\
\pm 1.02\end{array}$ & -2.88 \\
\hline $\begin{array}{c}\text { Lee et al. } \\
2013 \\
28\end{array}$ & $\begin{array}{c}\text { OnDemand } \\
\text { 3D }\end{array}$ & 48 & 108 & Open & $\begin{array}{l}\text { Fully } \\
\text { guided }\end{array}$ & Both & $\begin{array}{c}\text { Teeth/ } \\
\text { Mucosa }\end{array}$ & $\begin{array}{l}\text { Fixed/ } \\
\text { Non- } \\
\text { fixed }\end{array}$ & $1.09 \pm 1.1$ & - & $1.56 \pm 1.48$ & - & $3.8 \pm 3.24$ & - & & - \\
\hline $\begin{array}{c}\text { Ochi et al. } \\
2013 \\
29\end{array}$ & Procera & 15 & 30 & Flapless & $\begin{array}{l}\text { Fully } \\
\text { guided }\end{array}$ & Mandible & Mucosa & Fixed & $0.89 \pm 0.44$ & 2.66 & $1.08 \pm 0.47$ & 2.21 & & - & $\begin{array}{l}-0.28 \\
\pm 0.61\end{array}$ & 1.22 \\
\hline $\begin{array}{c}\text { Vieira et } \\
\text { al. } \\
2013^{30}\end{array}$ & $\begin{array}{c}\text { Dental } \\
\text { Slice }\end{array}$ & 14 & 62 & Flapless & $\begin{array}{l}\text { Fully } \\
\text { guided }\end{array}$ & Both & Mucosa & Fixed & $1.81 \pm 0.82$ & - & $2.24 \pm 1.67$ & - & $1.89 \pm 0.54$ & - & - & - \\
\hline $\mathrm{a}$ & & - & 32 & & & Maxila & & & $2.17 \pm 0.87$ & & $2.86 \pm 2.17$ & & $1.9 \pm 0.17$ & & & \\
\hline $\mathrm{b}$ & & & 30 & & & Mandible & & & $1.42 \pm 0.76$ & & $1.57 \pm 0.84$ & & $1.85 \pm 0.75$ & & & \\
\hline $\begin{array}{c}\text { Cassetta et } \\
\text { al. } \\
2014^{31}\end{array}$ & Simplant & 28 & 225 & Flapless & Fully & Both & Mucosa & $\begin{array}{l}\text { Fixed/ } \\
\text { Non- } \\
\text { fixed }\end{array}$ & $1.68 \pm 0.6$ & - & $2.19 \pm 0.83$ & - & $4.67 \pm 2.68$ & - & - & - \\
\hline $\mathrm{a}$ & & 18 & 145 & & & Both & & Fixed & $1.66 \pm 0.58$ & & $2.09 \pm 0.75$ & & $4.09 \pm 2.4$ & & & \\
\hline $\mathrm{b}$ & & 10 & 80 & & & & & $\begin{array}{l}\text { Non- } \\
\text { fixed }\end{array}$ & $1.68 \pm 0.6$ & & $2.26 \pm 0.89$ & & $5.62 \pm 2.8$ & & & \\
\hline c & & 18 & 145 & & & Maxilla & & $\begin{array}{l}\text { Fixed/ } \\
\text { Non- }\end{array}$ & $1.68 \pm 0.51$ & & $2.12 \pm 0.78$ & & $4.36 \pm 2.9$ & & & \\
\hline $\mathrm{d}$ & & 10 & 80 & & & Mandible & & fixed & $1.64 \pm 0.71$ & & $2.25 \pm 0.88$ & & $5.46 \pm 2.03$ & & & \\
\hline $\begin{array}{c}\text { Cassetta et } \\
\text { al. } \\
2014^{32} \\
\end{array}$ & Simplant & 24 & 172 & Flapless & $\begin{array}{l}\text { Fully } \\
\text { guided }\end{array}$ & Both & Mucosa & Fixed & $1.1 \pm 0.39$ & - & - & - & $4.33 \pm 1.42$ & - & - & - \\
\hline $\begin{array}{r}\text { Stübinger et } \\
\text { al. } 2014^{33}\end{array}$ & Facilitate & 10 & 44 & Open & $\begin{array}{l}\text { Fully } \\
\text { guided }\end{array}$ & Both & Bone & Fixed & $0.71 \pm 0.4$ & 1.77 & $0.77 \pm 0.38$ & 1.78 & $2.39 \pm 0.97$ & 4.52 & $\begin{array}{c}0.47 \\
\pm 0.43\end{array}$ & 1.68 \\
\hline $\begin{array}{c}\text { Testori et } \\
\text { al. } 2014 \\
34\end{array}$ & Simplant & 25 & 117 & $\begin{array}{l}\text { Open/ } \\
\text { Flapless }\end{array}$ & $\begin{array}{l}\text { Fully } \\
\text { guided }\end{array}$ & Both & $\begin{array}{c}\text { Mucosa / } \\
\text { Teeth/ } \\
\text { Teeth }+ \\
\text { Mucosa }\end{array}$ & - & $1.32 \pm 0.67$ & - & $1.52 \pm 0.67$ & - & $3.26 \pm 2.24$ & - & - & - \\
\hline
\end{tabular}




\begin{tabular}{|c|c|c|c|c|c|c|c|c|c|c|c|c|c|c|c|c|}
\hline $\begin{array}{l}\text { Study, } \\
\text { subgroup }\end{array}$ & $\begin{array}{l}\text { Implant planning } \\
\text { system }\end{array}$ & $\begin{array}{c}\text { Number } \\
\text { of } \\
\text { patients }\end{array}$ & $\begin{array}{l}\text { Number } \\
\text { of } \\
\text { implants }\end{array}$ & $\begin{array}{r}\text { Method of } \\
\text { surgery }\end{array}$ & $\begin{array}{c}\text { Implant } \\
\text { insertion } \\
\text { method }\end{array}$ & Jaw & $\begin{array}{l}\text { Guide } \\
\text { fixation } \\
\text { method }\end{array}$ & $\begin{array}{r}\text { Guide } \\
\text { fixation }\end{array}$ & $\begin{array}{c}\text { Implant } \\
\text { collar } \\
\text { deviation } \\
(\mathrm{mm}) \\
\pm \mathrm{SD}\end{array}$ & $\begin{array}{l}\text { Max. } \\
\text { (mm) }\end{array}$ & $\begin{array}{c}\text { Implant } \\
\text { apex } \\
\text { deviation } \\
(\mathrm{mm}) \\
{[\mathrm{SD}]}\end{array}$ & $\begin{array}{l}\text { Max. } \\
(\mathrm{mm})\end{array}$ & $\begin{array}{c}\text { Implant } \\
\text { axis } \\
\text { deviation } \\
\text { (degree) } \\
\text { [SD] }\end{array}$ & $\begin{array}{c}\text { Max } \\
\text { (degree) }\end{array}$ & $\begin{array}{c}\text { Depth } \\
\text { deviation } \\
(\mathrm{mm}) \\
{[\mathrm{SD}]}\end{array}$ & $\begin{array}{l}\text { Max. } \\
(\mathrm{mm})\end{array}$ \\
\hline $\begin{array}{c}\text { Vercruyssen } \\
\text { et al. } 2014 \\
35\end{array}$ & $\begin{array}{c}\text { Materialise Universal/ } \\
\text { Facilitate }\end{array}$ & 48 & 209 & $\begin{array}{l}\text { Flapless/ } \\
\text { Open }\end{array}$ & $\begin{array}{l}\text { Fully } \\
\text { guided } \\
\text { / Half } \\
\text { guided } \\
\end{array}$ & \multirow[t]{5}{*}{ Both } & $\begin{array}{c}\text { Mucosa/ } \\
\text { Bone }\end{array}$ & $\begin{array}{l}\text { Fixed/ } \\
\text { Non- } \\
\text { fixed }\end{array}$ & $\begin{array}{c}1.38 \\
\pm 0.95\end{array}$ & 3.73 & $\begin{array}{c}1.58 \\
\pm 0.74\end{array}$ & 3.66 & $3.14 \pm 2.06$ & 16.03 & - & - \\
\hline $\mathrm{a}$ & \multirow[t]{2}{*}{ Materialise Universal } & 12 & 55 & Flapless & \multirow[t]{2}{*}{$\begin{array}{l}\text { Half } \\
\text { guided }\end{array}$} & & Mucosa & $\begin{array}{l}\text { Non- } \\
\text { fixed }\end{array}$ & $1.23 \pm 0.6$ & 2.65 & $\begin{array}{c}1.57 \\
\pm 0.71\end{array}$ & 2.99 & $2.86 \pm 1.6$ & 7.6 & & \\
\hline $\mathrm{b}$ & & 12 & 53 & Open & & & Bone & Fixed & $1.6 \pm 0.92$ & 3.73 & $\begin{array}{r}1.65 \\
\pm 0.82 \\
\end{array}$ & 3.66 & $3.79 \pm 2.36$ & 10.05 & & \\
\hline c & \multirow[t]{2}{*}{ Facilitate } & 12 & 52 & Flapless & \multirow{2}{*}{$\begin{array}{l}\text { Half } \\
\text { guided }\end{array}$} & & Mucosa & $\begin{array}{l}\text { Non- } \\
\text { fixed }\end{array}$ & $\begin{array}{r}1.38 \\
\pm 1.33 \\
\end{array}$ & 2.68 & $1.6 \pm 0.7$ & 3.27 & $2.71 \pm 1.36$ & 6.36 & & \\
\hline$d$ & & 12 & 49 & Open & & & Bone & Fixed & $\begin{array}{r}1.33 \\
\pm 0.82 \\
\end{array}$ & 3.58 & $1.5 \pm 0.72$ & 3.56 & $3.2 \pm 2.7$ & 16.03 & & \\
\hline $\begin{array}{c}\text { Cassetta et al. } \\
2015^{36} \\
\end{array}$ & \multirow[t]{3}{*}{ Simplant } & 10 & 66 & Flapless & \multirow[t]{3}{*}{$\begin{array}{l}\text { Fully } \\
\text { guided }\end{array}$} & Both & Mucosa & Fixed & - & - & - & - & $4.3 \pm 2.45$ & 14.34 & \multirow[t]{3}{*}{-} & \multirow[t]{3}{*}{-} \\
\hline $\mathrm{a}$ & & - & 40 & & & Maxilla & & & & & & & $3.96 \pm 2.68$ & 14.34 & & \\
\hline $\mathrm{b}$ & & & 26 & & & Mandible & & & & & & & $4.81 \pm 1.99$ & 9.81 & & \\
\hline $\begin{array}{c}\text { Sun et al. } 2015 \\
37\end{array}$ & \multirow[t]{3}{*}{ Procera } & 15 & 80 & Flapless & \multirow[t]{3}{*}{$\begin{array}{l}\text { Fully } \\
\text { guided }\end{array}$} & Both & \multirow[t]{3}{*}{ Mucosa } & \multirow[t]{3}{*}{ Fixed } & $\begin{array}{c}1.48 \\
\pm 0.96\end{array}$ & 5.42 & - & - & $3.33 \pm 2.32$ & 11.6 & $\begin{array}{c}0.83 \\
\pm 0.71\end{array}$ & 4.7 \\
\hline $\mathrm{a}$ & & - & 44 & & & Maxilla & & & $\begin{array}{c}1.31 \\
\pm 0.86 \\
\end{array}$ & 2.12 & & & $2.73 \pm 1.17$ & 5.6 & $\begin{array}{c}0.65 \\
\pm 0.37 \\
\end{array}$ & 1.7 \\
\hline $\mathrm{b}$ & & & 36 & & & Mandible & & & $\begin{array}{r}1.69 \\
\pm 1.05 \\
\end{array}$ & 5.42 & & & $4.05 \pm 3.07$ & 11.6 & $\begin{array}{c}1.04 \\
\pm 0.94 \\
\end{array}$ & 4.7 \\
\hline $\begin{array}{c}\text { Vercruyssen } \\
\text { et al. } 2015 \\
38\end{array}$ & $\begin{array}{c}\text { Materialise Universal/ } \\
\text { Facilitate }\end{array}$ & 48 & 209 & $\begin{array}{l}\text { Flapless/ } \\
\text { Open }\end{array}$ & $\begin{array}{l}\text { Fully } \\
\text { guided } \\
/ \text { Half } \\
\text { guided } \\
\end{array}$ & Both & $\begin{array}{c}\text { Mucosa / } \\
\text { Bone }\end{array}$ & $\begin{array}{l}\text { Fixed/ } \\
\text { Non- } \\
\text { fixed }\end{array}$ & - & - & - & - & - & - & $0.9 \pm 0.8$ & 3.65 \\
\hline $\mathrm{a}$ & Materialise Universal & 12 & 55 & Flapless & $\begin{array}{c}\text { Half } \\
\text { quided }\end{array}$ & & Mucosa & $\begin{array}{l}\text { Non- } \\
\text { fixed }\end{array}$ & & & & & & & $\begin{array}{c}0.74 \\
\pm 0.57 \\
\end{array}$ & 2.42 \\
\hline $\mathrm{b}$ & & 12 & 53 & Open & & & Bone & Fixed & & & & & & & $\begin{array}{c}1.18 \\
\pm 0.94 \\
\end{array}$ & 3.65 \\
\hline c & Facilitate & 12 & 52 & Flapless & $\begin{array}{c}\text { Fully } \\
\text { quided }\end{array}$ & & Mucosa & $\begin{array}{l}\text { Non- } \\
\text { fixed }\end{array}$ & & & & & & & $\begin{array}{c}0.74 \\
\pm 0.65 \\
\end{array}$ & 2.32 \\
\hline $\mathrm{d}$ & & 12 & 49 & Open & & & Bone & Fixed & & & & & & & $1 \pm 0.69$ & 3.00 \\
\hline $\begin{array}{l}\text { Verhamme et } \\
\text { al. } 2015^{39}\end{array}$ & Procera & 25 & 150 & Flapless & $\begin{array}{l}\text { Fully } \\
\text { guided }\end{array}$ & Maxilla & Mucosa & $\begin{array}{l}\text { Fixed/ } \\
\text { Non- } \\
\text { fixed }\end{array}$ & $\begin{array}{c}1.96 \\
\pm 0.23\end{array}$ & 7.82 & $\begin{array}{c}2.29 \\
\pm 0.27\end{array}$ & 8.73 & $3.93 \pm 0.41$ & 19.8 & $\begin{array}{l}-0.58 \\
\pm 0.16\end{array}$ & -4.11 \\
\hline $\begin{array}{l}\text { Verhamme et } \\
\text { al. } 2015^{40}\end{array}$ & Procera & 30 & 104 & Flapless & $\begin{array}{l}\text { Fully } \\
\text { guided }\end{array}$ & Maxilla & Mucosa & $\begin{array}{l}\text { Fixed/ } \\
\text { Non- } \\
\text { fixed }\end{array}$ & $\begin{array}{c}1.37 \\
\pm 0.33\end{array}$ & 4.21 & $\begin{array}{c}1.59 \\
\pm 0.35\end{array}$ & 4.33 & $2.82 \pm 0.71$ & 13.47 & $\begin{array}{l}-0.84 \\
\pm 0.44 \\
\end{array}$ & -1.53 \\
\hline $\begin{array}{l}\text { Wiele et al. } \\
2015^{41}\end{array}$ & Simplant & 16 & 75 & Flapless & $\begin{array}{c}\text { Fully } \\
\text { guided }\end{array}$ & Both & Mucosa & Fixed & $0.87 \pm 0.5$ & 2.76 & $1.1 \pm 0.53$ & 2.69 & $2.78 \pm 1.48$ & 7.04 & $0.48 \pm 0.5$ & 2.42 \\
\hline $\begin{array}{c}\text { Lee et al. } 2016 \\
42\end{array}$ & R2GATE & 11 & 21 & Flapless & $\begin{array}{c}\text { Fully } \\
\text { guided }\end{array}$ & Both & Teeth & - & $1.3 \pm 1.42$ & - & - & - & - & - & $\begin{array}{c}0.93 \\
\pm 0.38 \\
\end{array}$ & - \\
\hline $\begin{array}{c}\text { Cassetta et al. } \\
2017^{43}\end{array}$ & $\begin{array}{l}\text { 3Diagnosy } \\
\mathrm{s}\end{array}$ & 10 & 70 & Flapless & $\begin{array}{l}\text { Fully } \\
\text { guided }\end{array}$ & Both & Mucosa & Fixed & $\begin{array}{c}0.68 \\
\pm 0.22\end{array}$ & 1.01 & $0.86 \pm 0.4$ & 1.99 & $3.14 \pm 2.24$ & 9.22 & - & - \\
\hline
\end{tabular}

Tab. 3. Dependence of linear abutment deviation of inserted implants on research characteristics.

\begin{tabular}{|c|c|c|c|c|c|}
\hline \multirow{2}{*}{\multicolumn{2}{|c|}{ esearch characteristics }} & \multicolumn{3}{|c|}{ Implant collar deviation } & \multirow[b]{2}{*}{$\mathrm{p}$ value } \\
\hline & & \multirow{2}{*}{$\begin{array}{c}\text { Average deviation (mm) } \\
1.17 \\
\end{array}$} & \multicolumn{2}{|c|}{ 95\% CI the lower bound $95 \% \mathrm{CI}$ the upper bound } & \\
\hline n method & Open & & 0.77 & 1.58 & \multirow{2}{*}{0.631} \\
\hline & Flapless & 1.28 & 0.98 & 1.58 & \\
\hline \multirow[t]{4}{*}{ lacement type } & With guide & 1.27 & 1.03 & 1.52 & \multirow{2}{*}{0.464} \\
\hline & Without guide & 1.42 & 1.22 & 1.62 & \\
\hline & Maxilla & 1.43 & 1.07 & 1.79 & \multirow{2}{*}{0.337} \\
\hline & Mandibula & 1.18 & 0.85 & 1.51 & \\
\hline \multirow{3}{*}{ utment } & Mucosa & 1.27 & 0.95 & 1.59 & \multirow{3}{*}{0.892} \\
\hline & Teeth & 1.41 & 1.09 & 1.73 & \\
\hline & Bone & 1.21 & 0.63 & 1.78 & \\
\hline \multirow{2}{*}{ ation } & Fixated & 1.19 & 0.98 & 1.40 & \multirow{2}{*}{0.106} \\
\hline & Not fixated & 1.47 & 1.33 & 1.62 & \\
\hline \multicolumn{2}{|c|}{ rall $\left(\mathrm{I}^{2}=99.34, \mathrm{p}<0.01\right)$} & 1.25 & 1.00 & 1.51 & - \\
\hline
\end{tabular}

CI- confidence interval; 
Tab. 4 Dependence of linear apex deviation of inserted implants on research characteristics.

\begin{tabular}{|c|c|c|c|c|c|}
\hline \multirow{2}{*}{\multicolumn{2}{|c|}{ esearch characteristics }} & \multicolumn{3}{|c|}{ Implant apex deviation } & \multirow[b]{2}{*}{ p value } \\
\hline & & \multirow{2}{*}{$\begin{array}{c}\text { Average deviation (mm) } \\
1.36 \\
\end{array}$} & \multicolumn{2}{|c|}{$95 \% \mathrm{CI}$ the lower bound $95 \% \mathrm{CI}$ the upper bound } & \\
\hline$a$ method & Open & & 0.86 & 1.86 & \multirow{2}{*}{0.506} \\
\hline & Flapless & 1.56 & 1.14 & 1.97 & \\
\hline \multirow[t]{4}{*}{ lacement type } & With guide & 1.55 & 1.22 & 1.88 & \multirow{2}{*}{0.631} \\
\hline & Without guide & 1.69 & 1.53 & 1.84 & \\
\hline & Maxilla & 1.71 & 1.19 & 2.23 & \multirow{2}{*}{0.298} \\
\hline & Mandibula & 1.31 & 0.80 & 1.81 & \\
\hline \multirow{3}{*}{ atment } & Mucosa & 1.53 & 1.10 & 1.96 & \multirow{3}{*}{0.626} \\
\hline & Teeth & 1.82 & 1.45 & 2.19 & \\
\hline & Bone & 1.30 & 0.70 & 1.90 & \\
\hline \multirow{2}{*}{ ation } & Fixated & 1.39 & 1.08 & 1.69 & \multirow{2}{*}{0.035} \\
\hline & Not fixated & 1.85 & 1.62 & 2.09 & \\
\hline \multicolumn{2}{|c|}{ rall $\left(\mathrm{I}^{2}=99.41, \mathrm{p}<0.01\right)$} & 1.52 & 1.18 & 1.86 & - \\
\hline
\end{tabular}

CI- confidence interval;

Tab. 5 Dependence of angular deviation of inserted implants on research characteristics.

\begin{tabular}{|c|c|c|c|c|c|}
\hline \multirow{2}{*}{\multicolumn{2}{|c|}{ esearch characteristics }} & \multicolumn{3}{|c|}{ Implant axis deviation } & \multirow[b]{2}{*}{$\mathrm{p}$ value } \\
\hline & & Average deviation (degree) & 95\% CI the lower bound & $95 \%$ CI the upper bound & \\
\hline \multirow[t]{2}{*}{ a method } & Open & 3.27 & 2.44 & 4.10 & \multirow{2}{*}{0.843} \\
\hline & Flapless & 3.36 & 2.83 & 3.89 & \\
\hline \multirow[t]{4}{*}{ lacement type } & With guide & 3.47 & 3.03 & 3.92 & \multirow{2}{*}{0.442} \\
\hline & Without guide & 3.89 & 2.60 & 5.19 & \\
\hline & Maxilla & 3.27 & 2.26 & 4.28 & \multirow{2}{*}{0.296} \\
\hline & Mandibula & 4.03 & 1.86 & 6.21 & \\
\hline \multirow{3}{*}{ stment } & Mucosa & 3.34 & 2.80 & 3.88 & \multirow{3}{*}{0.815} \\
\hline & Teeth & 3.68 & 2.32 & 5.04 & \\
\hline & Bone & 3.09 & 2.16 & 4.03 & \\
\hline \multirow{2}{*}{ ation } & Fixated & 3.37 & 2.75 & 3.99 & \multirow{2}{*}{0.079} \\
\hline & Not fixated & 4.22 & 3.08 & 5.37 & \\
\hline \multicolumn{2}{|c|}{ rall $\left(\mathrm{I}^{2}=98.56, \mathrm{p}<0.01\right)$} & 3.47 & 3.01 & 3.94 & - \\
\hline
\end{tabular}

CI- pasikliautinumo intervalas;

Tab. 6 Dependence of linear depth deviation of inserted implants on research characteristics.

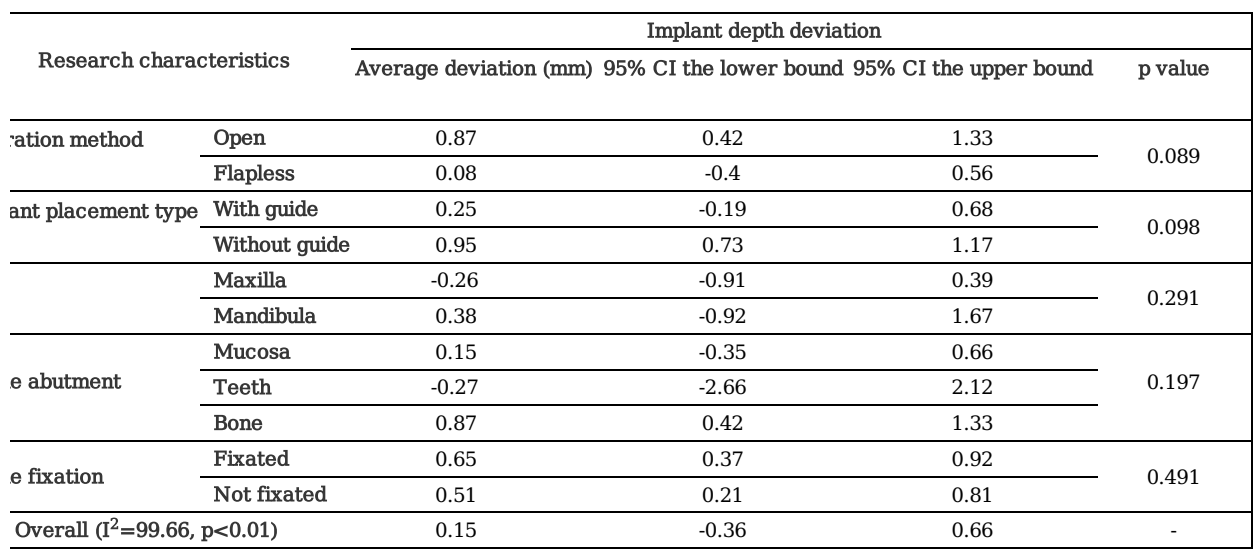


CI- confidence interval;

\section{Figures}

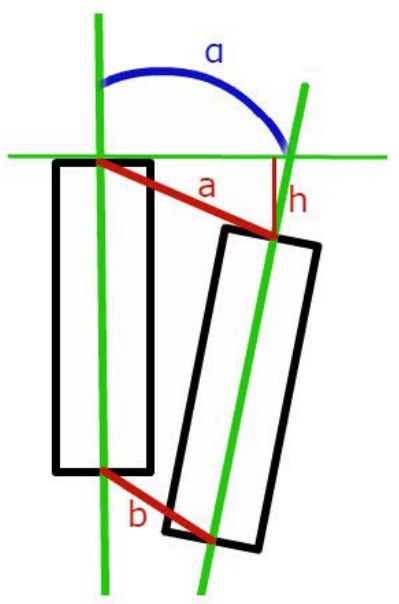

\section{Figure 1}

Diagram of implant deviation measurement. a- angular deviation of the implant axis a- linear deviation of implant collar b - linear deviation of implant axis h- linear deviation of implant depth 


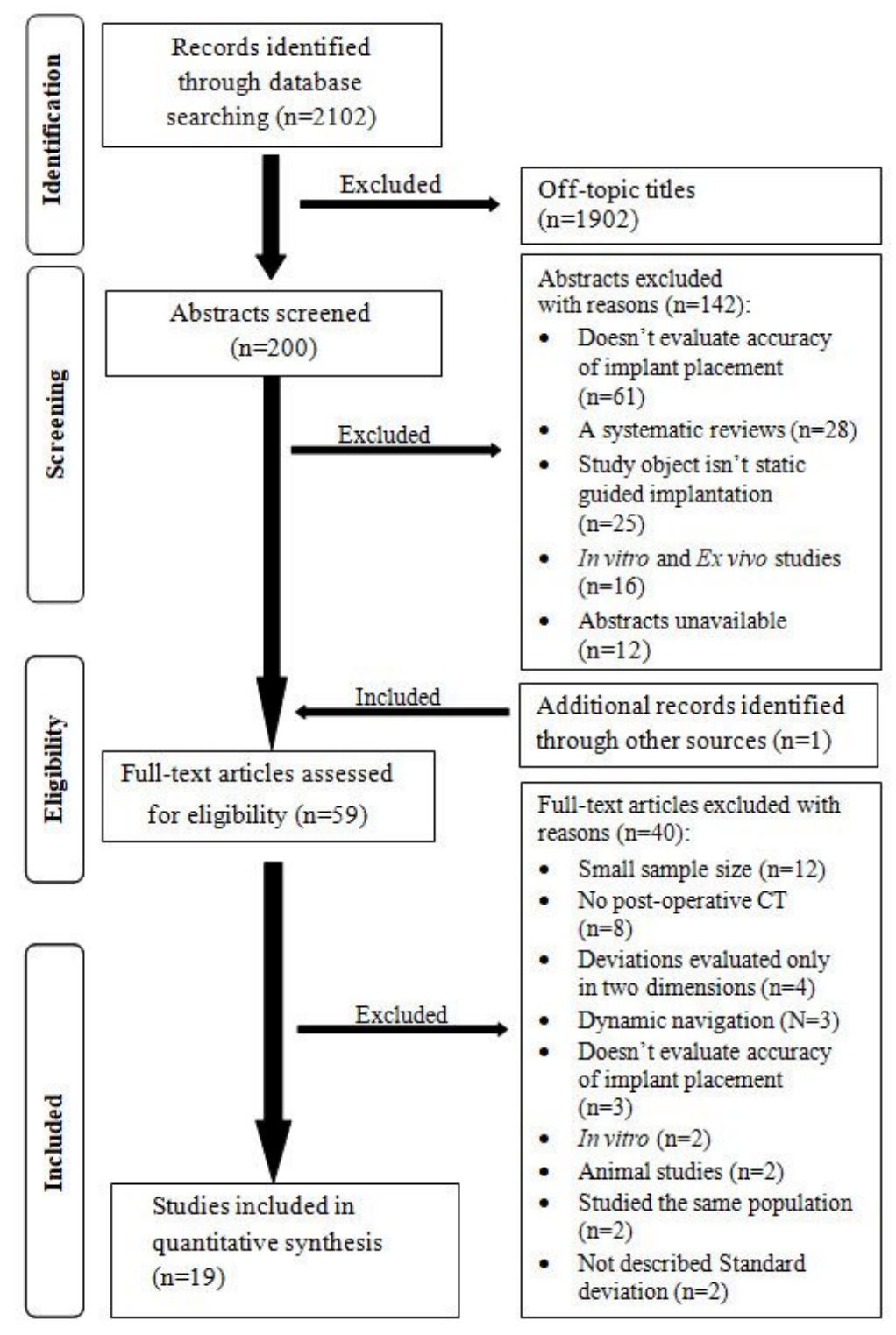

\section{Figure 2}

Scheme of systematic selection of scientific publications 


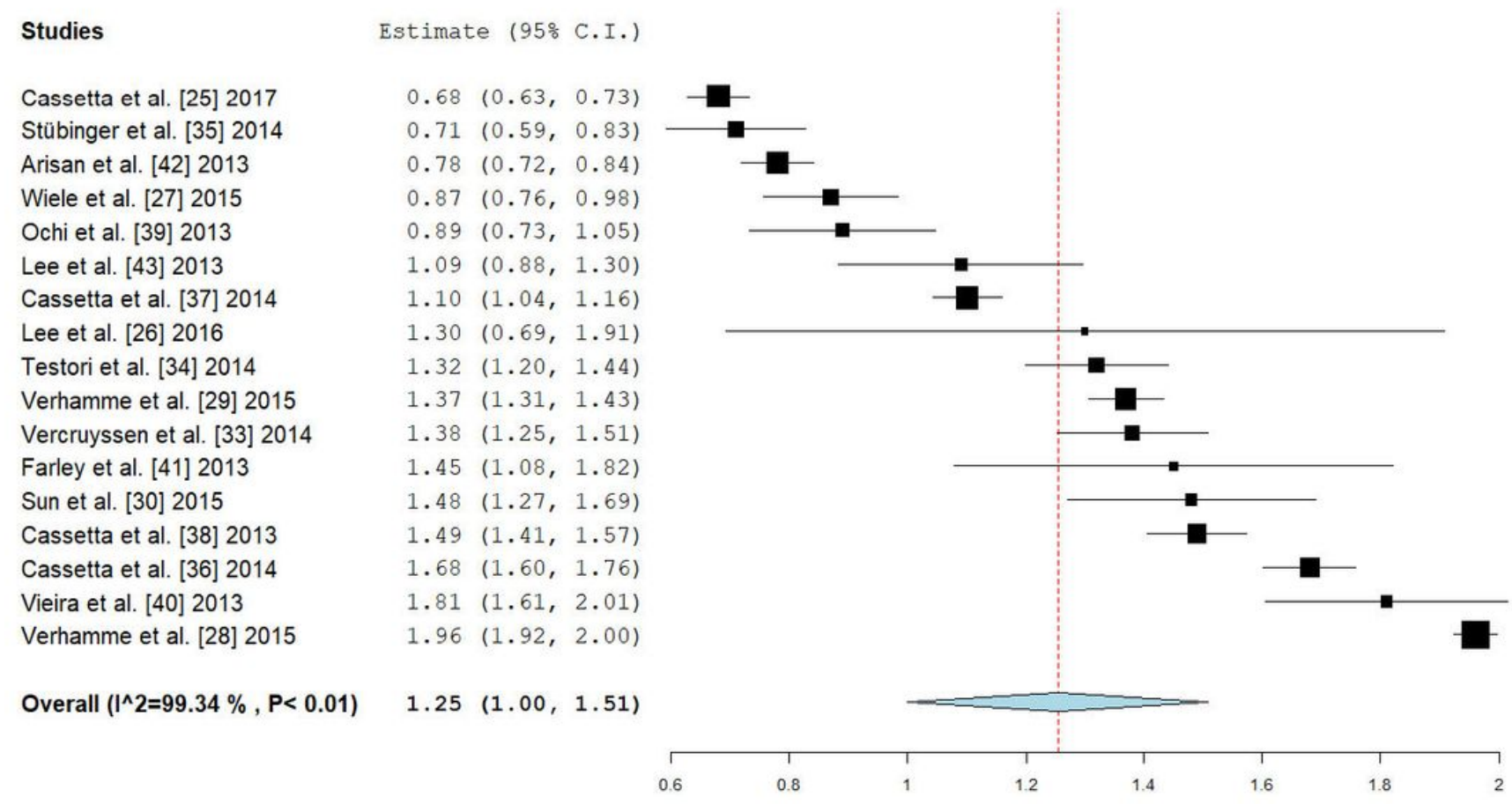

\section{Figure 3}

Total linear deviation of the implant in the collar area 


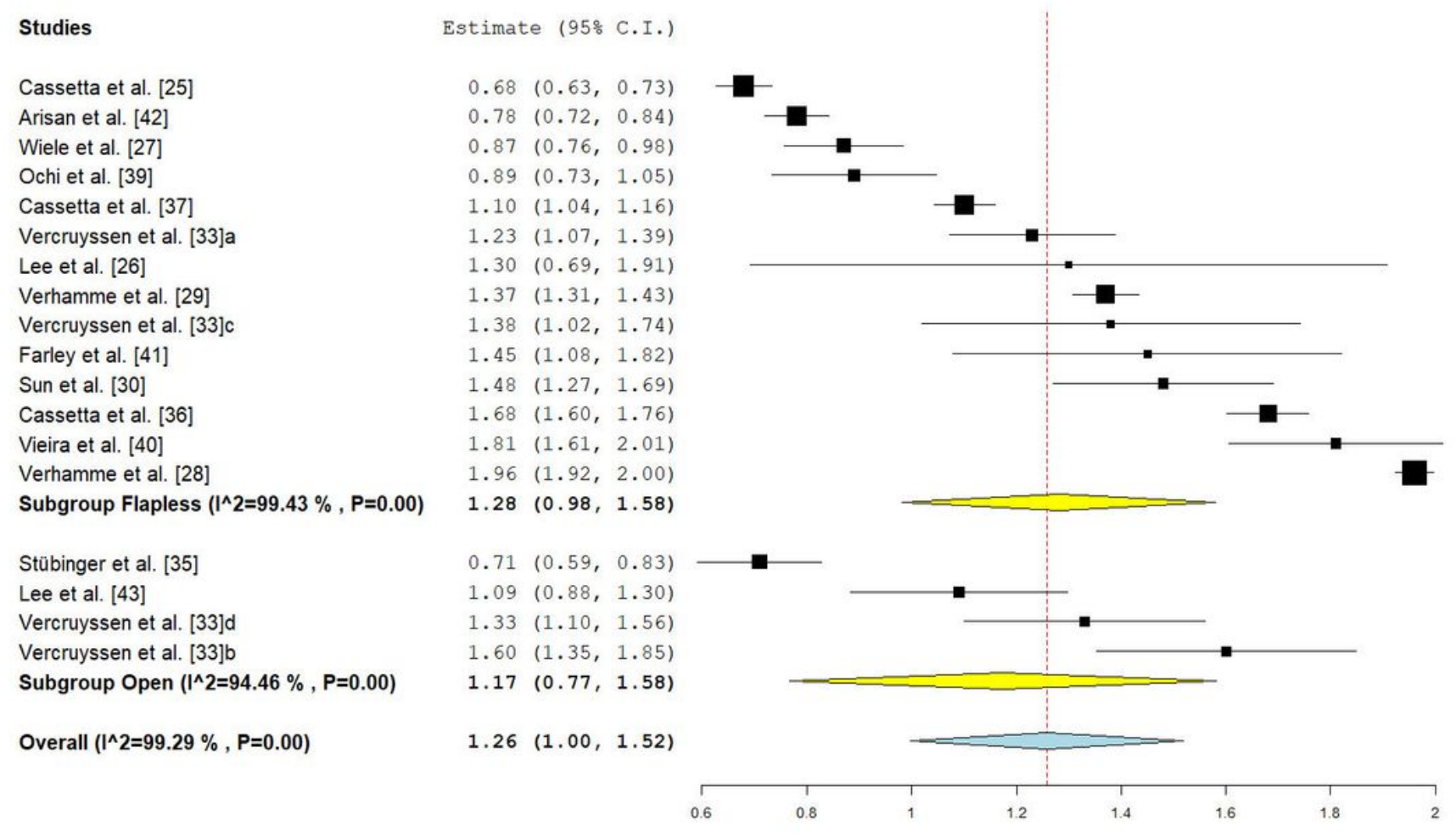

\section{Figure 4}

Linear deviation of the implant in the collar area, categorized according to the surgical technique 
Studies

Cassetta et al. [25]

Stübinger et al. [35]

Arisan et al. [42]

Wiele et al. [27]

Ochi et al. [39]

Lee et al. [43]

Cassetta et al. [37]

Lee et al. [26]

Testori et al. [34]

Vercruyssen et al. [33]d

Verhamme et al. [29]

Vercruyssen et al. [33]c

Farley et al. [41]

Sun et al. [30]

Cassetta et al. [38]b

Cassetta et al. [38]c

Cassetta et al. [36]

Vieira et al. [40]

Verhamme et al. [28]

Subgroup Fully guided $\left(I^{\wedge} 2=99.25 \%, P=0.00\right)$

Vercruyssen et al. [33]a

Cassetta et al. [38]a

Vercruyssen et al. [33]b

Subgroup Half guided $\left(I^{\wedge} 2=75.35 \%, P=0.02\right)$

Overall $\left(I^{\wedge} 2=99.13 \%, P=0.00\right)$
Estimate (95\% C.I.)

$0.68(0.63,0.73)$

$0.71(0.59,0.83)$

$0.78(0.72,0.84)$

$0.87(0.76,0.98)$

$0.89(0.73,1.05)$

$1.09(0.88,1.30)$

$1.10(1.04,1.16)$

$1.30(0.69,1.91)$

$1.32(1.20,1.44)$

$1.33(1.10,1.56)$

$1.37(1.31,1.43)$

$1.38(1.02,1.74)$

$1.45(1.08,1.82)$

$1.48(1.27,1.69)$

$1.49(1.33,1.65)$

$1.55(1.39,1.71)$

$1.68(1.60,1.76)$

$1.81(1.61,2.01)$

$1.96(1.92,2.00)$

$1.27(1.03,1.52)$

$1.23(1.07,1.39)$

$1.47(1.35,1.59)$

$1.60(1.35,1.85)$

$1.42(1.22,1.62)$

$1.29(1.07,1.52)$

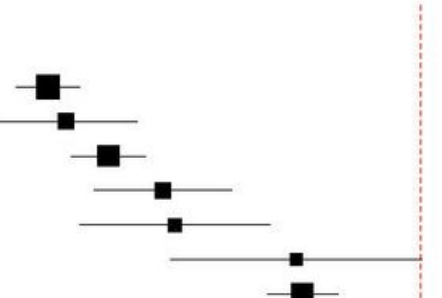

-

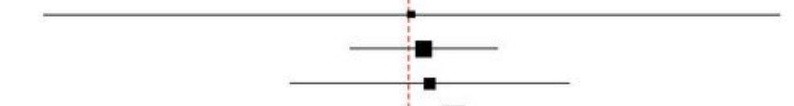

(2)
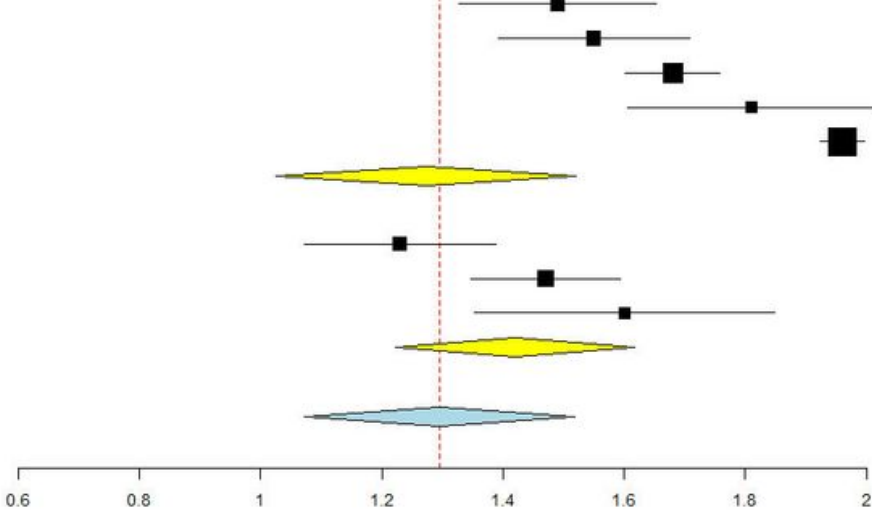

Figure 5

Linear deviation of the implant in the collar area, categorized according to the implant insertion method 
Studies

Arisan et al. [42]e

Arisan et al. [42]b

Sun et al. [30]a

Verhamme et al. [29]

Cassetta et al. [36]c

Verhamme et al. [28]

Vieira et al. [40]a

Subgroup Maxilla ( $\left.\left.\right|^{\wedge} 2=99.15 \%, P=0.00\right)$

Arisan et al. [42]f

Arisan et al. [42]c

Ochi et al. [39]

Vieira et al. [40]b

Cassetta et al. [36]d

Sun et al. [30]b

Subgroup Mandible ( $\left.\left.\right|^{\wedge} 2=95.82 \%, P=0.00\right)$

Overall $\left(I^{\wedge} 2=98.99 \%, P=0.00\right)$
Estimate (95\% C.I.)

$0.73(0.60,0.86)$

$0.82(0.69,0.95)$

$1.31(1.06,1.56)$

$1.37(1.31,1.43)$

$1.68(1.60,1.76)$

$1.96(1.92,2.00)$

$2.17(1.87,2.47)$

$1.43(1.07,1.79)$

$0.74(0.62,0.86)$

$0.80(0.68,0.92)$

$0.89(0.73,1.05)$

$1.42(1.15,1.69)$

$1.64(1.48,1.80)$

$1.69(1.35,2.03)$

$1.18(0.85,1.51)$

$1.32(1.03,1.61)$
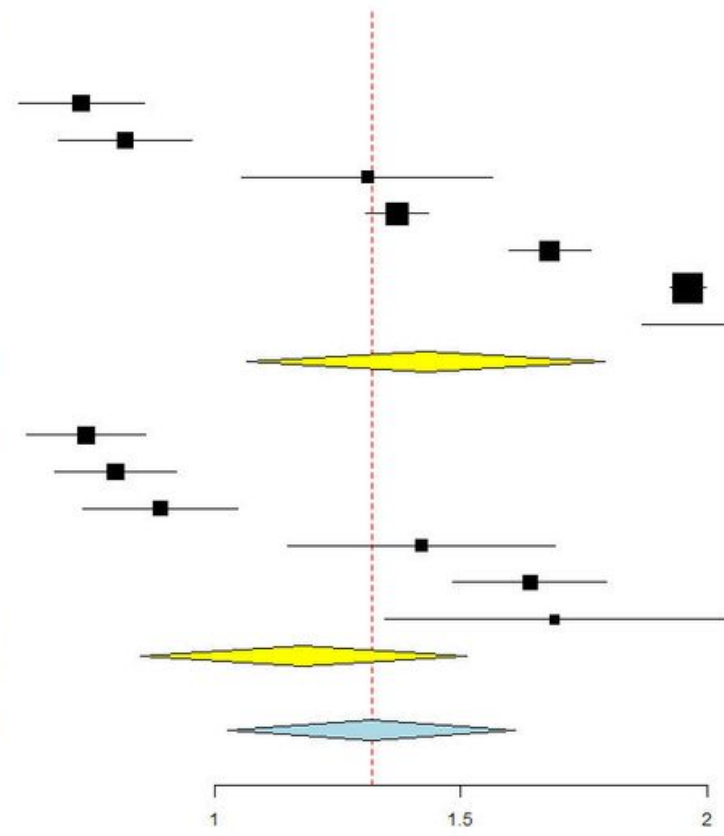

Figure 6

Linear deviation of the implant in the collar area, categorized by the jaw

Studies

Cassetta et al. [25]

Arisan et al. [42]

Wiele et al. [27]

Ochi et al. [39]

Cassetta et al. [37]

Vercruyssen et al. [33]a

Verhamme et al. [29]

Vercruyssen et al. [33]c

Sun et al. [30]

Cassetta et al. [36]

Vieira et al. [40]

Verhamme et al. [28]

Subgroup Mucosa $\left(I^{\wedge} 2=99.52 \%, P=0.00\right)$

Stübinger et al. [35]

Vercruyssen et al. [33]d

Vercruyssen et al. [33]b

Subgroup Bone $\left(\left.\right|^{\wedge} 2=96.21 \%, P=0.00\right)$

Lee et al. [26]

Farley et al. [41]

Subgroup Teeth $\left(I^{\wedge} 2=0 \%, P=0.68\right)$

Overall $\left(I^{\wedge} 2=99.33 \%, P=0.00\right)$
Estimate (95\% C.I.)

$0.68(0.63,0.73)$

$0.78(0.72,0.84)$

$0.87(0.76,0.98)$

$0.89(0.73,1.05)$

$1.10(1.04,1.16)$

$1.23(1.07,1.39)$

$1.37(1.31,1.43)$

$1.38(1.02,1.74)$

$1.48(1.27,1.69)$

$1.68(1.60,1.16)$

$1.81(1.61,2.01)$

$1.96(1.92,2.00)$

$1.27(0.95,1.59)$

$0.71(0.59,0.83)$

$1.33(1.10,1.56)$

$1.60(1.35,1.85)$

$1.21(0.63,1.78)$

$1.30(0.69,1.91)$

$1.45(1.08,1.82)$

$1.41(1.09,1.73)$

$1.27(1.00,1.54)$
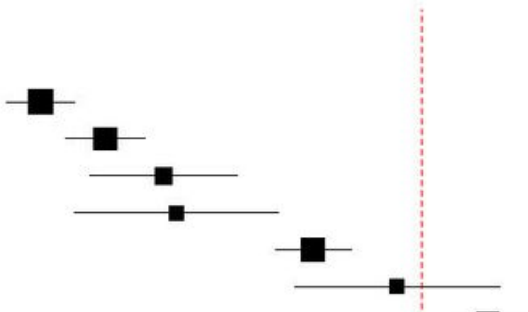

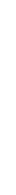
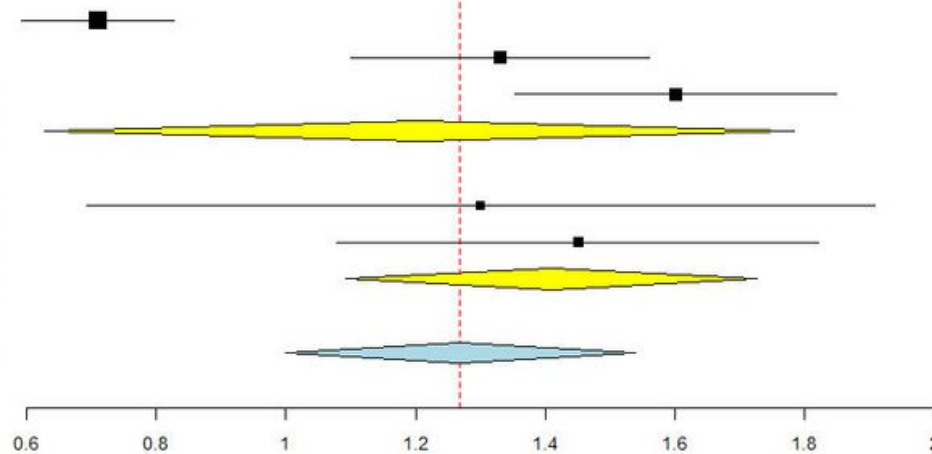


\section{Figure 7}

Linear deviation of the implant in the collar area, categorized by type of guide support tissue

\section{Studies}

Cassetta et al. [25]

Stübinger et al. [35]

Arisan et al. [42]

Wiele et al. [27]

Ochi et al. [39]

Cassetta et al. [37]

Vercruyssen et al. [33]d

Sun et al. [30]

Cassetta et al. [38]b

Vercruyssen et al. [33]b

Cassetta et al. [36]a

Vieira et al. [40]

Subgroup Fixed (I^2=98.05\%,P=0.00)

Vercruyssen et al. [33]a

Vercruyssen et al. [33]c

Farley et al. [41]

Cassetta et al. [38]a

Cassetta et al. [38]c

Cassetta et al. [36]b

Subgroup Non-fixed (I^2=74.23\%, P=0.00)

Overall $\left(I^{\wedge} 2=97.83 \%, P=0.00\right)$
Estimate (95\% C.I.)

$0.68(0.63,0.73)$

$0.71(0.59,0.83)$

$0.78(0.72,0.84)$

$0.87(0.76,0.98)$

$0.89(0.73,1.05)$

$1.10(1.04,1.16)$

$1.33(1.10,1.56)$

$1.48(1.27,1.69)$

$1.49(1.33,1.65)$

$1.60(1.35,1.85)$

$1.66(1.57,1.75)$

$1.81(1.61,2.01)$

$1.19(0.98,1.40)$

$1.23(1.07,1.39)$

$1.38(1.02,1.74)$

$1.45(1.08,1.82)$

$1.47(1.35,1.59)$

$1.55(1.39,1.71)$

$1.68(1.55,1.81)$

$1.47(1.33,1.62)$

$1.28(1.10,1.46)$
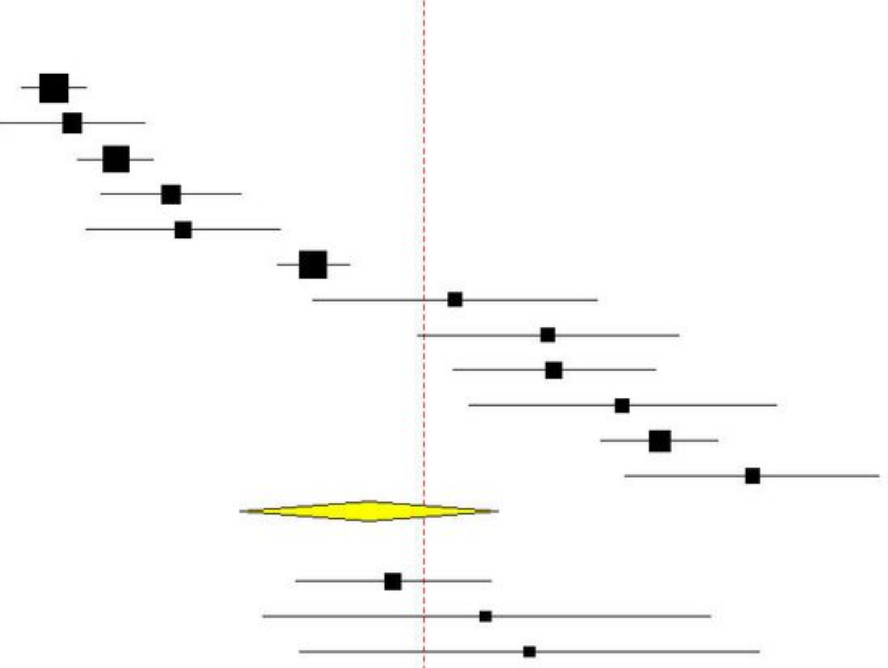
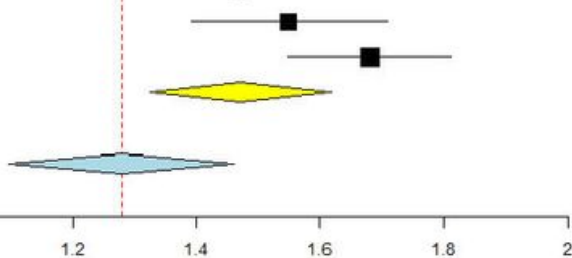

Figure 8

Linear deviation of the implant in the collar area, categorized by guide fixation method 


\section{Studies}

Stübinger et al. [35] 2014

Arisan et al. [42] 2013

Cassetta et al. [25] 2017

Ochi et al. [39] 2013

Wiele et al. [27] 2015

Testori et al. [34] 2014

Lee et al. [43] 2013

Vercruyssen et al. [33] 2014

Verhamme et al. [29] 2015

Farley et al. [41] 2013

Cassetta et al. [38] 2013

Cassetta et al. [36] 2014

Vieira et al. [40] 2013

Verhamme et al. [28] 2015

Overall $\left(I^{\wedge} 2=99.41 \%, P<0.01\right)$
Estimate (95\% C.I.)

$0.77(0.66,0.88)$

$0.84(0.78,0.90)$

$0.86(0.77,0.95)$

$1.08(0.91,1.25)$

$1.10(0.98,1.22)$

$1.52(1.40,1.64)$

$1.56(1.28,1.84)$

$1.58(1.48,1.68)$

$1.59(1.52,1.66)$

$1.82(1.45,2.19)$

$1.90(1.78,2.02)$

$2.19(2.08,2.30)$

$2.24(1.82,2.66)$

$2.29(2.25,2.33)$

$1.52(1.18,1.86)$

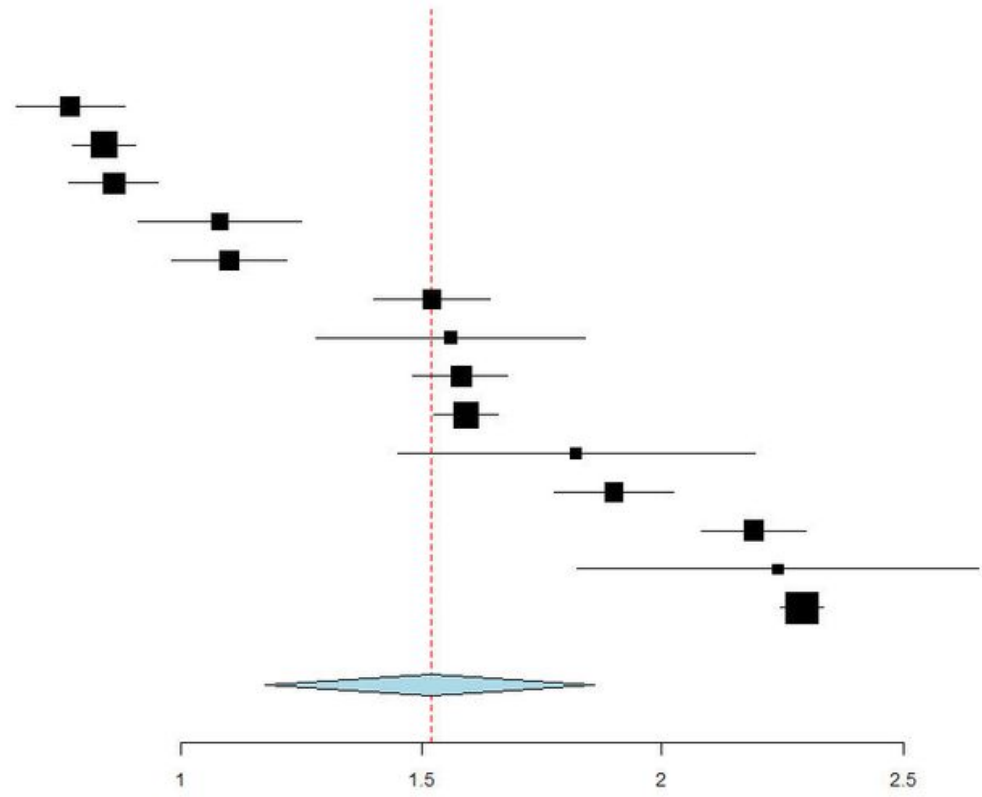

\section{Figure 9}

Total linear deviation of implant in apex area

\section{Studies}

Stübinger et al. [35]

Vercruyssen et al. [33]d

Lee et al. [43]

Vercruyssen et al. [33]b

Subgroup Open $\left(\left.\right|^{\wedge} 2=96.37 \%, P=0.00\right)$

Arisan et al. [42]

Cassetta et al. [25]

Ochi et al. [39]

Wiele et al. [27]

Vercruyssen et al. [33]a

Verhamme et al. [29]

Vercruyssen et al. [33]c

Farley et al. [41]

Cassetta et al. [36]

Vieira et al. [40]

Verhamme et al. [28]

Subgroup Flapless $\left(I^{\wedge} 2=99.49 \%, P=0.00\right)$

Overall $\left(I^{\wedge} 2=99.36 \%, P=0.00\right)$
Estimate (95\% C.I.)

$0.77(0.66,0.88)$

$1.50(1.30,1.70)$

$1.56(1.28,1.84)$

$1.65(1.43,1.87)$

$1.36(0.86,1.86)$

$0.84(0.78,0.90)$

$0.86(0.77,0.95)$

$1.08(0.91,1.25)$

$1.10(0.98,1.22)$

$1.57(1.38,1.76)$

$1.59(1.52,1.66)$

$1.60(1.41,1.79)$

$1.82(1.45,2.19)$

$2.19(2.08,2.30)$

$2.24(1.82,2.66)$

$2.29(2.25,2.33)$

$1.56(1.14,1.97)$

$1.51(1.16,1.85)$

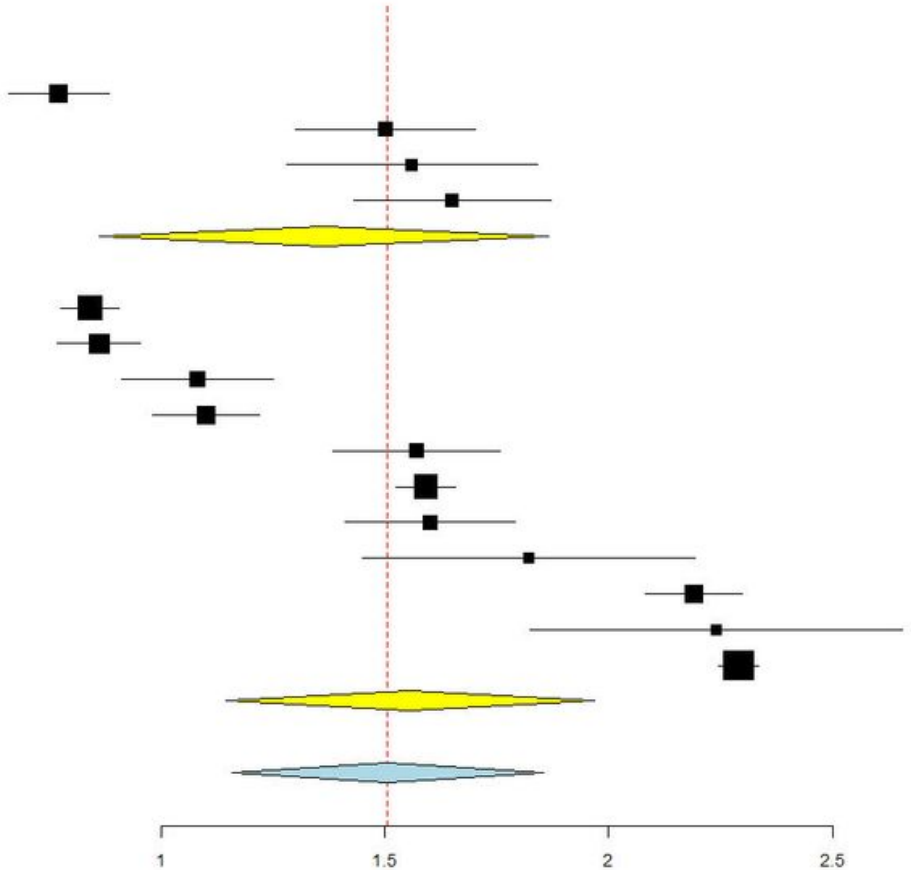




\section{Figure 10}

Linear deviation of the implant in the apex area, categorized by surgical technique

Studies

Farley et al. [41]

Verhamme et al. [29]

Verhamme et al. [28]

Ochi et al. [39]

Stübinger et al. [35]

Wiele et al. [27]

Cassetta et al. [38]c

Vercruyssen et al. [32]c

Sun et al. [30]

Cassetta et al. [38]b

Lee et al. [26]

Vercruyssen et al. [32]d

Subgroup Fully guided $\left(I^{\wedge} 2=99.48 \%, P=0.00\right)$

Vercruyssen et al. [32]a

Cassetta et al. [38]a

Vercruyssen et al. [32]b

Subgroup Half guided $\left(\left.\right|^{\wedge} 2=80.71 \%, P=0.01\right)$

Overall $\left(I^{\wedge} 2=99.5 \%, P=0.00\right)$
Estimate (95\% C.I.)

$-1.51(-2.14,-0.88)$

$-0.84(-0.92,-0.76)$

$-0.58(-0.61,-0.55)$

$-0.28(-0.50,-0.06)$

$0.47 \quad(0.34,0.60)$

$0.48 \quad(0.37,0.59)$

$0.63 \quad(0.52,0.74)$

$0.74 \quad(0.56, \quad 0.92)$

$0.83 \quad(0.67,0.99)$

$0.85 \quad(0.69,1.01)$

$0.93(0.77,1.09)$

$1.00 \quad(0.81,1.19)$

$0.25(-0.19,0.68)$

$0.74 \quad(0.59,0.89)$

$0.98 \quad(0.85,1.11)$

$1.18(0.93,1.43)$

$0.95 \quad(0.73,1.17)$

$0.39(-0.02,0.80)$

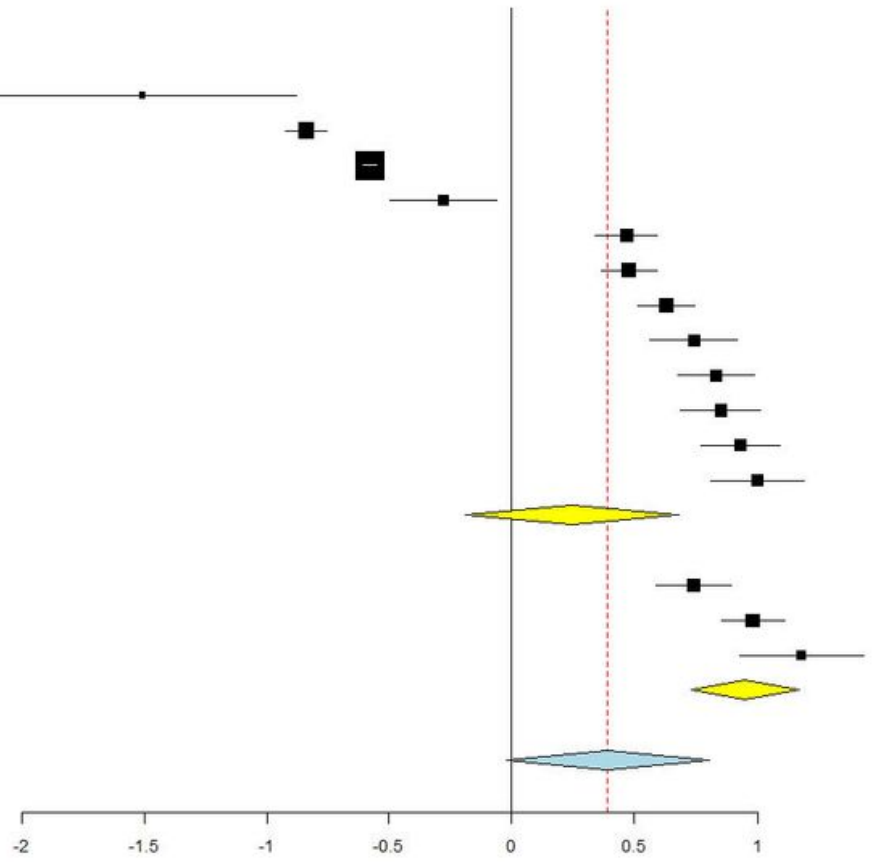

\section{Figure 11}

Linear deviation of the implant in the apex area, categorized by the implant insertion method

\section{Studies}

Arisan et al. [42]f

Arisan et al. [42]c

Ochi et al. [39]

Vieira et al. [40]b

Cassetta et al. [36]d

Subgroup Mandible $\left(I^{\wedge} 2=97.75 \%, P=0.00\right)$

Arisan et al. [42]e

Arisan et al. [42]b

Verhamme et al. [29]

Cassetta et al. [36]c

Verhamme et al. [28]

Vieira et al. [40]a

Subgroup Maxilla $\left(\left.\right|^{\wedge} 2=99.43 \%, P=0.00\right)$

Overall $\left(I^{\wedge} 2=99.31 \%, P=0.00\right)$
Estimate (95응 C.I.)

$0.77(0.63,0.91)$

$0.89(0.77,1.01)$

$1.08(0.91,1.25)$

$1.57(1.27,1.87)$

$2.25(2.06,2.44)$

$1.31(0.80,1.81)$

$0.81(0.67,0.95)$

$0.88(0.75,1.01)$

$1.59(1.52,1.66)$

$2.12(1.99,2.25)$

$2.29(2.25,2.33)$

$2.86(2.11,3.61)$

$1.71(1.19,2.23)$

$1.53(1.12,1.94)$

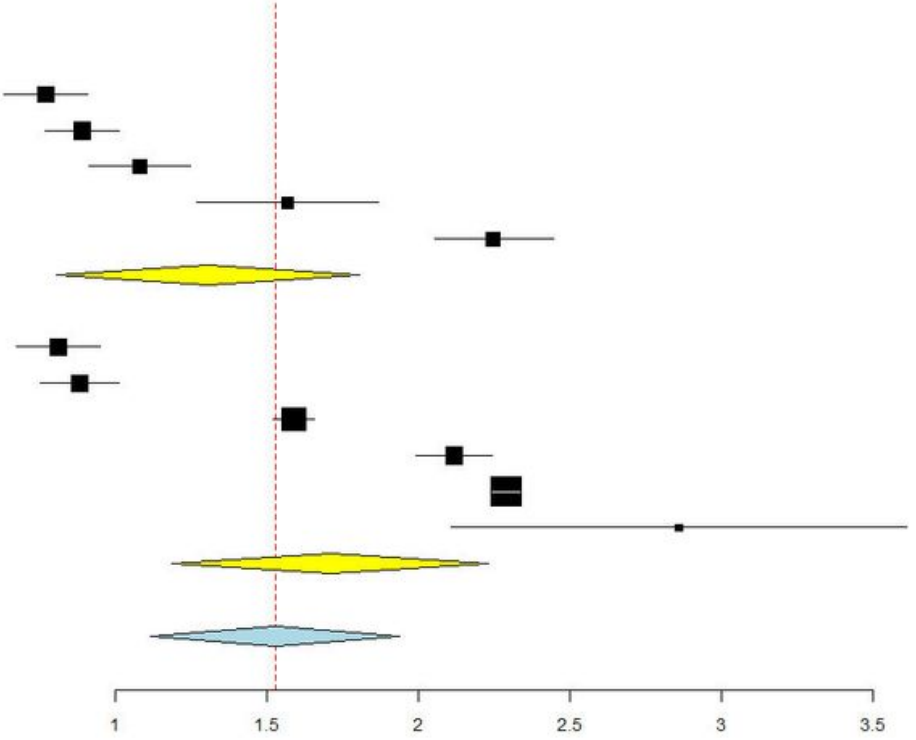




Studies
Stübinger et al. [35]
Vercruyssen et al. [33]d
Vercruyssen et al. [33]b
Subgroup Bone (I^2=97.2\%, P=0.00)
Arisan et al. [42]
Cassetta et al. [25]
Ochi et al. [39]
Wiele et al. [27]
Vercruyssen et al. [33]a
Verhamme et al. [29]
Vercruyssen et al. [33]c
Cassetta et al. [36]
Vieira et al. [40]
Verhamme et al. [28]
Subgroup Mucosa ( $\left.\left.\right|^{\wedge} 2=99.54 \%, P=0.00\right)$
Farley et al. [41]
Subgroup Teeth (I^2=NA , P=NA)
Overall (|^2=99.41 \% , P=0.00)

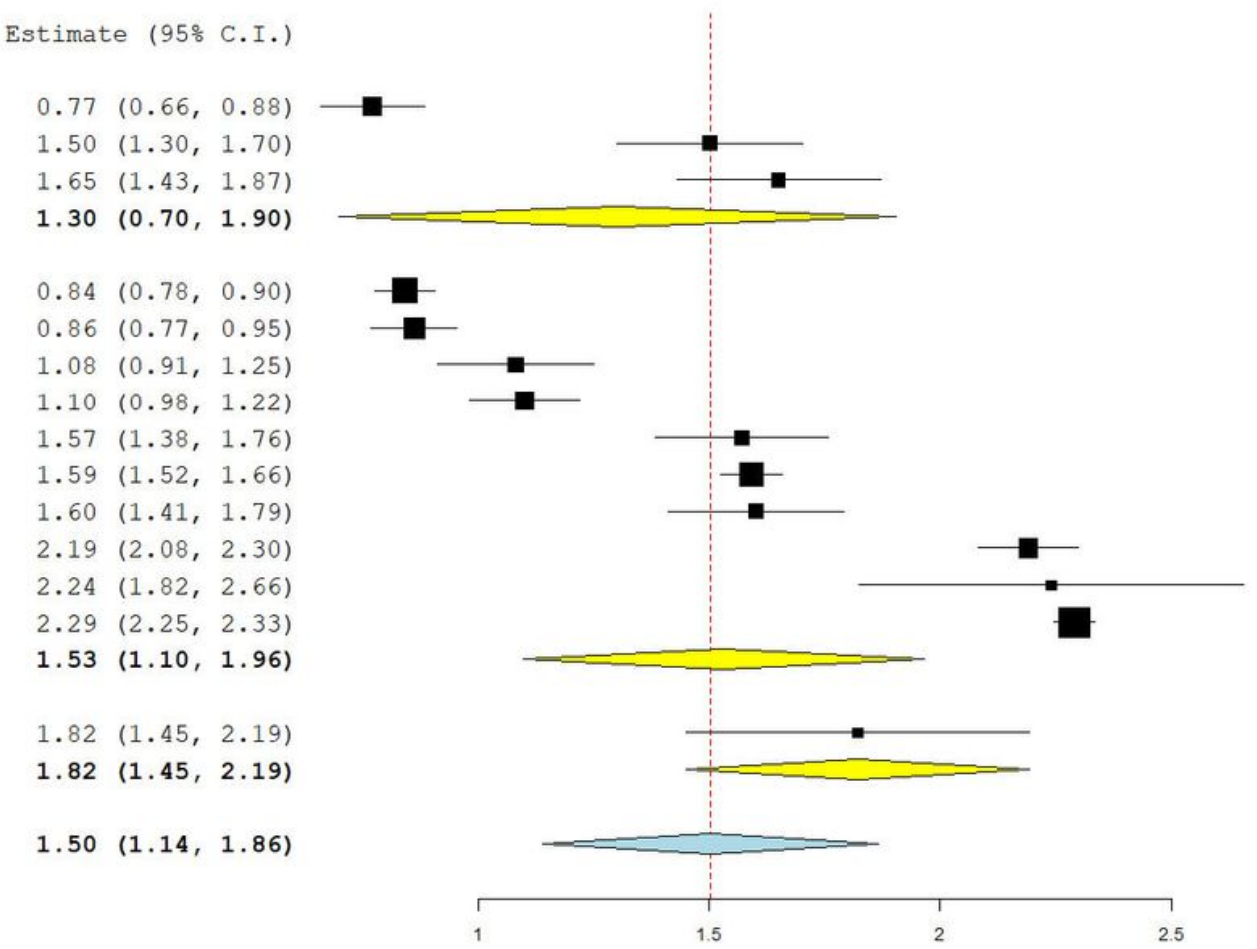

\section{Figure 13}

Linear deviation of the implant in the apex area, categorized by type of guide support tissue 


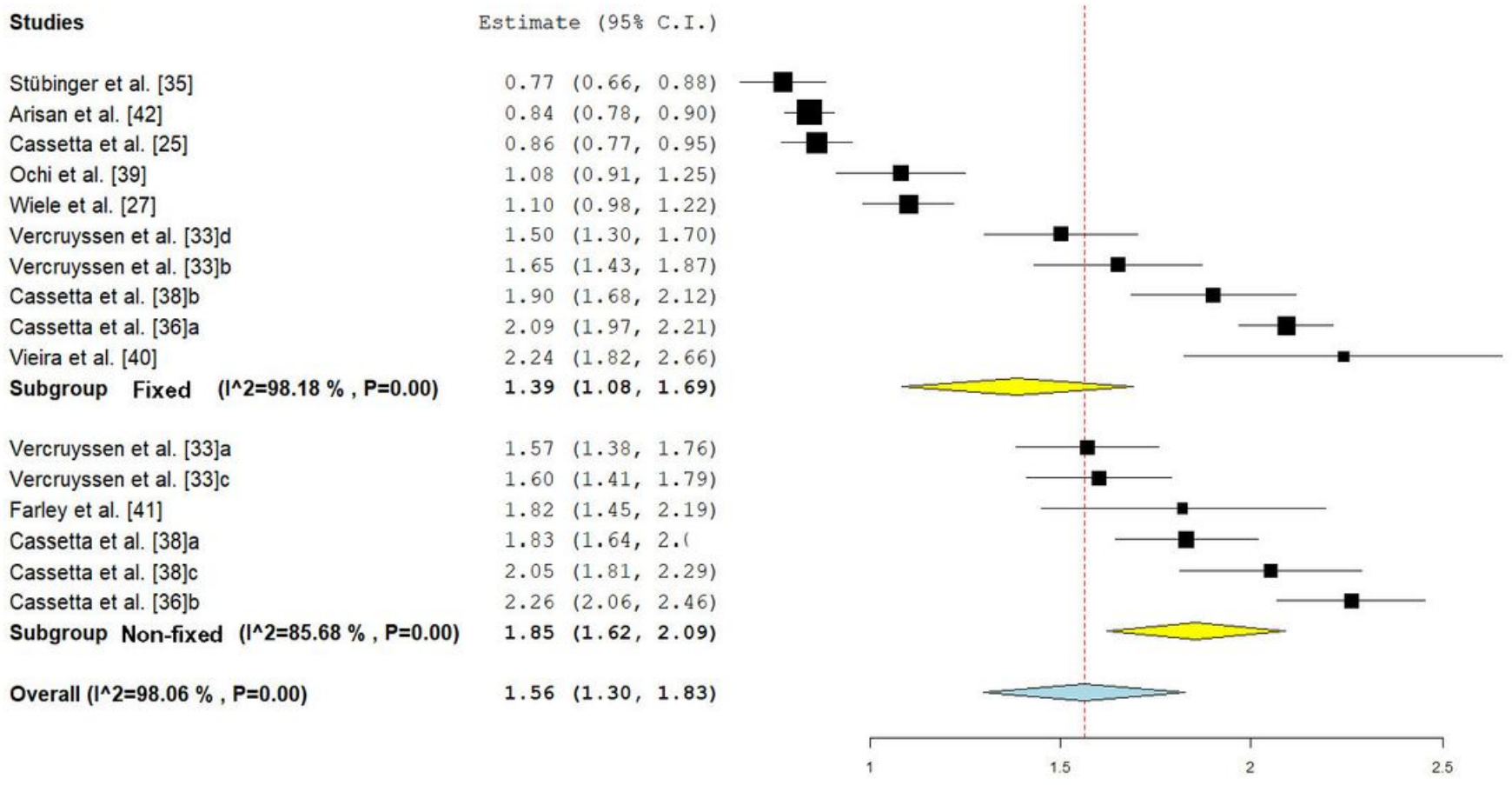

\section{Figure 14}

Linear deviation of the implant in the apex area, categorized by guide fixation method

Studies

Vieira et al. [40] 2013

Stübinger et al. [35] 2014

Wiele et al. [27] 2015

Verhamme et al. [29] 2015

Cassetta et al. [25] 2017

Vercruyssen et al. [33] 2014

Testori et al. [34] 2014

Sun et al. [30] 2015

Arisan et al. [42] 2013

Farley et al. [41] 2013

Lee et al. [43] 2013

Verhamme et al. [28] 2015

Cassetta et al. [31] 2015

Cassetta et al. [37] 2014

Cassetta et al. [36] 2014

Cassetta et al. [38] 2013
Estimate (95\% C.I.)

$1.89(1.76,2.02)$

$2.39(2.10,2.68)$

$2.78(2.45,3.11)$

$2.82(2.68,2.96)$

$3.14(2.62,3.66)$

$3.14(2.86,3.42)$

$3.26(2.85,3.67)$

$3.33(2.82,3.84)$

$3.39(3.17,3.61)$

$3.68(2.32,5.04)$

$3.80(3.19,4.41)$

$3.93(3.86,4.00)$

4.30 (3.71, 4.89)

$4.33(4.12,4.54)$

$4.67(4.32,5.02)$

$4.89(4.46,5.32)$

$3.47(3.01,3.94)$

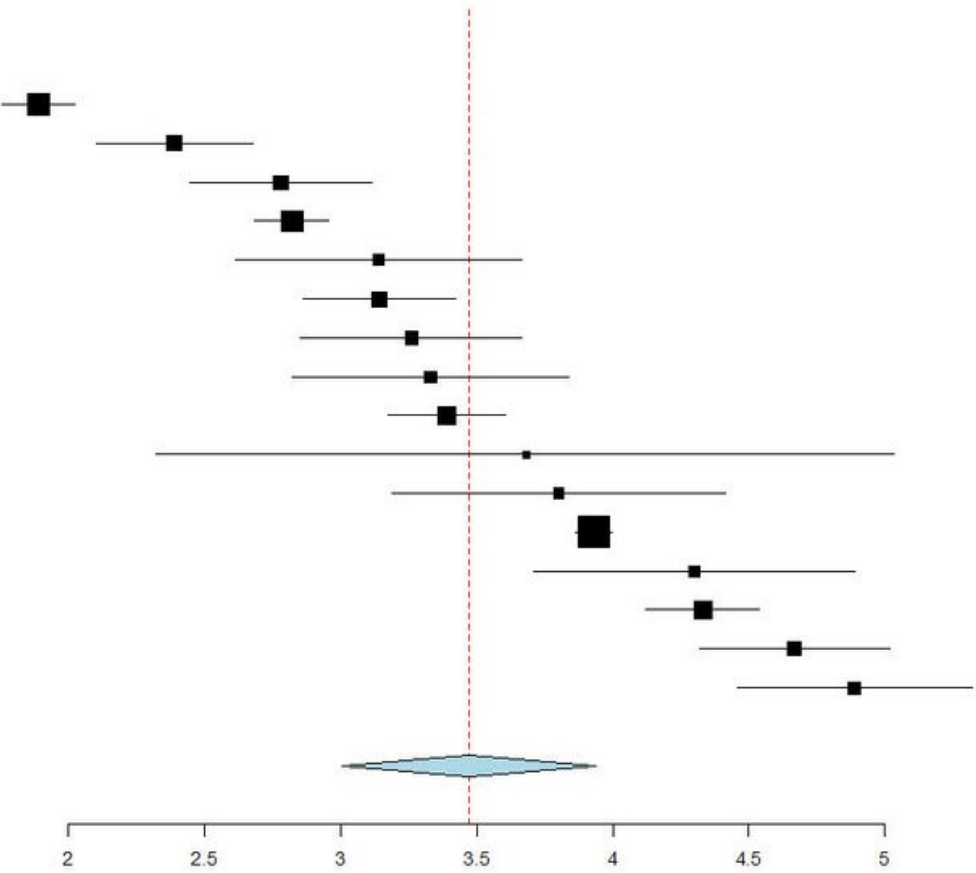




\section{Figure 15}

Overall angular deviation of the implant axis

Studies
Vieira et al. [40]
Vercruyssen et al. [33]c
Wiele et al. [27]
Verhamme et al. [29]
Vercruyssen et al. [33]a
Cassetta et al. [25]
Sun et al. [30]
Arisan et al. [42]
Farley et al. [41]
Verhamme et al. [28]
Cassetta et al. [31]
Cassetta et al. [37]
Cassetta et al. [36]
Subgroup Flapless (I^2=98.76 \% , P=0.00)
Stübinger et al. [35]
Vercruyssen et al. [33]d
Vercruyssen et al. [33]b
Lee et al. [43]
Subgroup Open (l^2=89.44 \% , P=0.00)
Overall (|^2=98.43 \% , P=0.00)

Estimate (95\% C.I.)

$1.89(1.76,2.02)$

$2.71(2.34,3.08)$

$2.78(2.45,3.11)$

$2.82(2.68,2.96)$

$2.86(2.44,3.28)$

$3.14(2.62,3.66)$

$3.33(2.82,3.84)$

$3.39(3.17,3.61)$

$3.68(2.32,5.04)$

$3.93(3.86,4.00)$

$4.30(3.71,4.89)$

$4.33(4.12,4.54)$

$4.67(4.32,5.02)$

$3.36(2.83,3.89)$

$2.39(2.10,2.68)$

$3.20(2.44,3.96)$

$3.79(3.15,4.43)$

$3.80(3.19,4.41)$

$3.27(2.44,4.10)$

$3.34(2.88,3.79)$

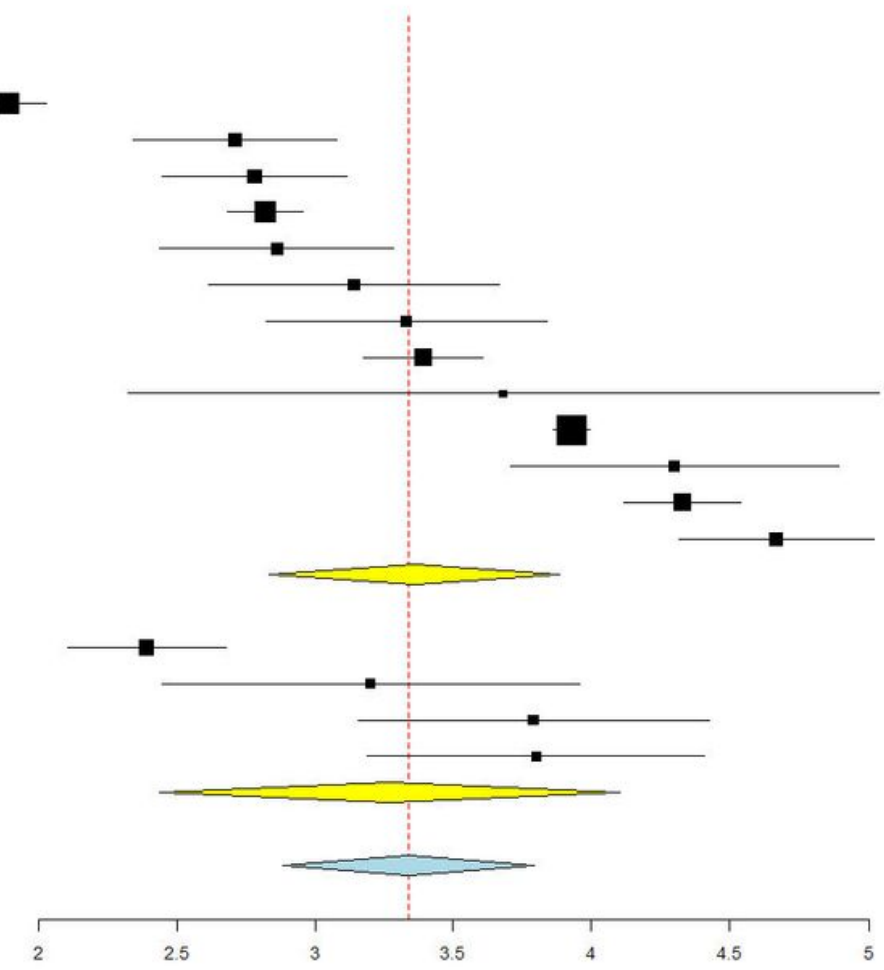

\section{Figure 16}

Angular deviation of implant axis, categorized by surgical technique 


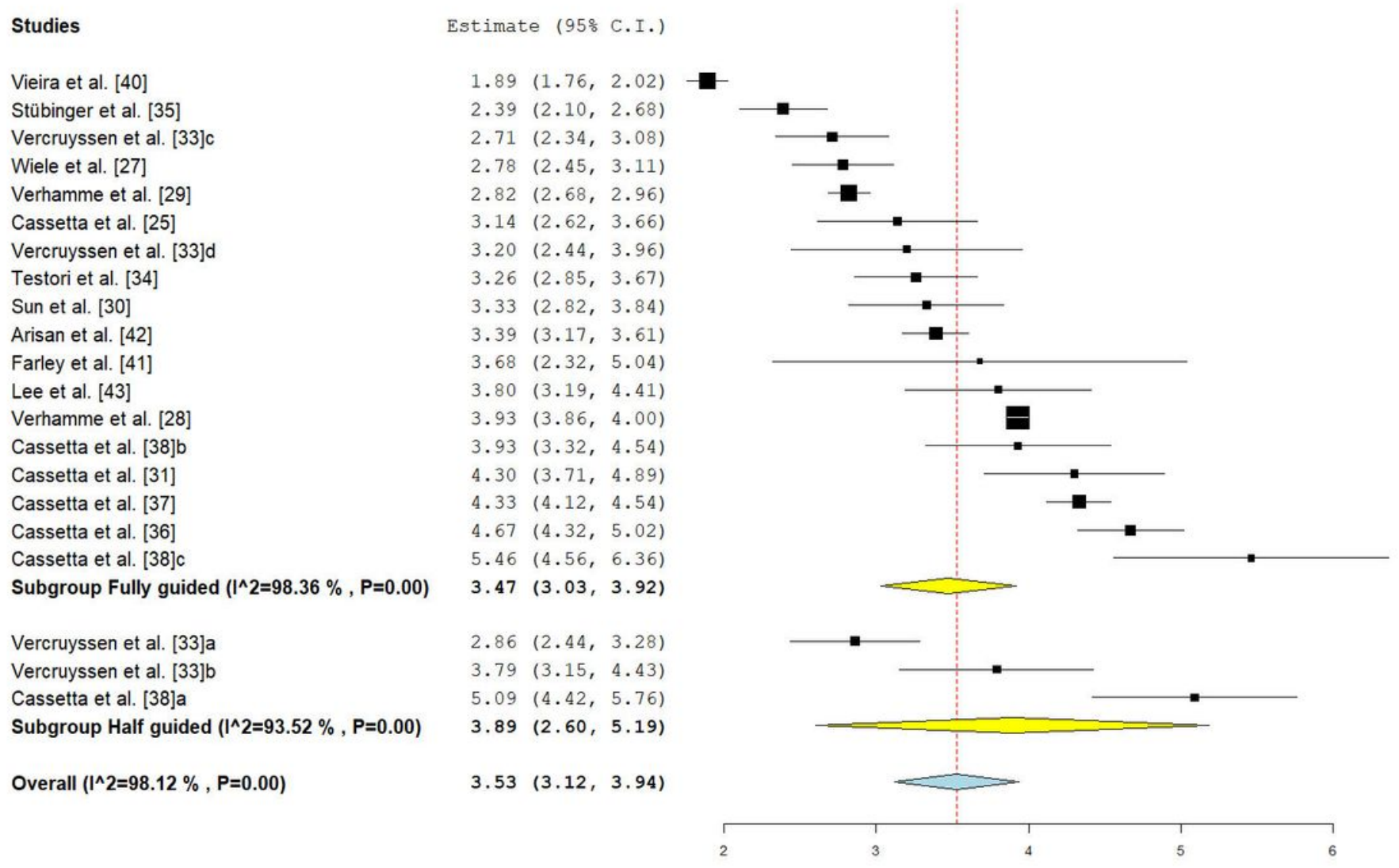

Figure 17

Angular deviation of implant axis, categorized according to implant insertion method. 
Studies
Vieira et al. [40]b
Sun et al. [30]b
Cassetta et al. [31]b
Cassetta et al. [36]d
Subgroup Mandible $\left(\left.\right|^{\wedge} 2=98.6 \%, P=0.00\right)$
Vieira et al. [40]a
Sun et al. [30]a
Verhamme et al. [29]
Verhamme et al. [28]
Cassetta et al. [31]a
Cassetta et al. [36]c
Subgroup Maxilla (l^2=99.76 \% , P=0.00)

Overall $\left(I^{\wedge} 2=99.61 \%, P=0.00\right)$
Estimate ( $95 \%$ C.I.)

$1.85(1.58,2.12)$

$4.05(3.05,5.05)$

$4.81(4.05,5.57)$

$5.46(5.02,5.90)$

$4.03(1.86,6.21)$

$1.90(1.84,1.96)$

$2.73(2.38,3.08)$

$2.82(2.68,2.96)$

$3.93(3.86,4.00)$

$3.96(3.13,4.79)$

$4.36(3.89,4.83)$

$3.27(2.26,4.28)$

$3.56(2.77,4.35)$

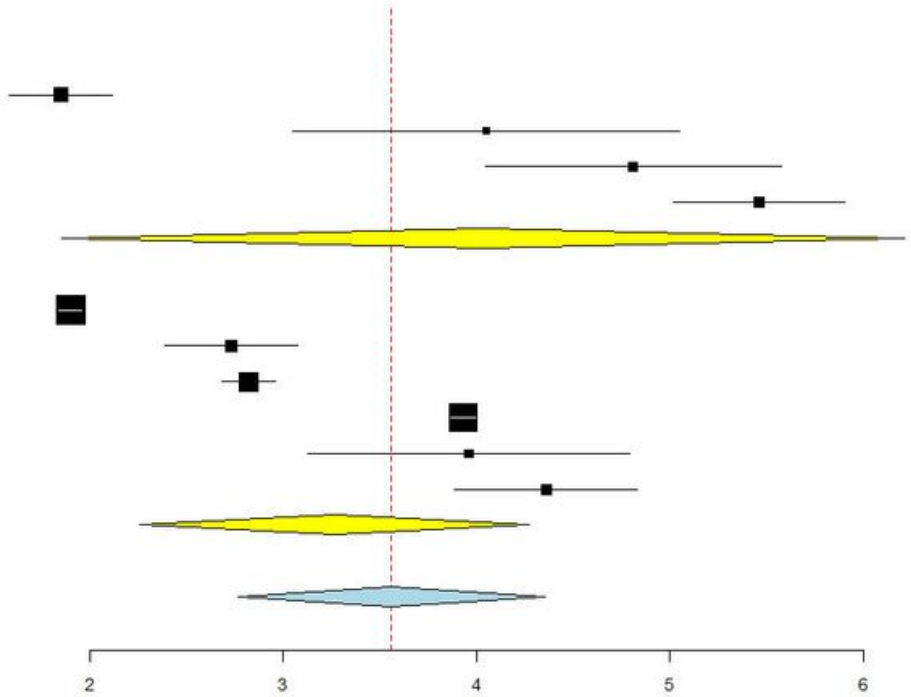

2

Figure 18

Angular deviation of implant axis categorized by jaw

Studies
Vieira et al. [40]
Vercruyssen et al. [33]c
Wiele et al. [27]
Verhamme et al. [29]
Vercruyssen et al. [33]a
Cassetta et al. [25]
Sun et al. [30]
Arisan et al. [42]
Verhamme et al. [28]
Cassetta et al. [31]
Cassetta et al. [37]
Cassetta et al. [36]
Subgroup Mucosa (I^2=98.86 \% , P=0.00)
Stübinger et al. [35]
Vercruyssen et al. [33]d
Vercruyssen et al. [33]b
Subgroup Bone (|^2=88.55 \% , P=0.00)
Farley et al. [41]
Subgroup Teeth (I^2=NA , P=NA)
Overall ( $\left.\left.\right|^{\wedge} 2=98.53 \%, P=0.00\right)$

Estimate (95\% C.I.)

$1.89(1.76,2.02)$

$2.71(2.34,3.08)$

$2.78(2.45,3.11)$

$2.82(2.68,2.96)$

$2.86(2.44,3.28)$

$3.14(2.62,3.66)$

$3.33(2.82,3.84)$

$3.39(3.17,3.61)$

$3.93(3.86,4.00)$

$4.30(3.71,4.89)$

$4.33(4.12,4.54)$

$4.67(4.32,5.02)$

$3.34(2.80,3.88)$

$2.39(2.10,2.68)$

$3.20(2.44,3.96)$

$3.79(3.15,4.43)$

$3.09(2.16,4.03)$

$3.68(2.32,5.04)$

$3.68(2.32,5.04)$

$3.31(2.84,3.78)$

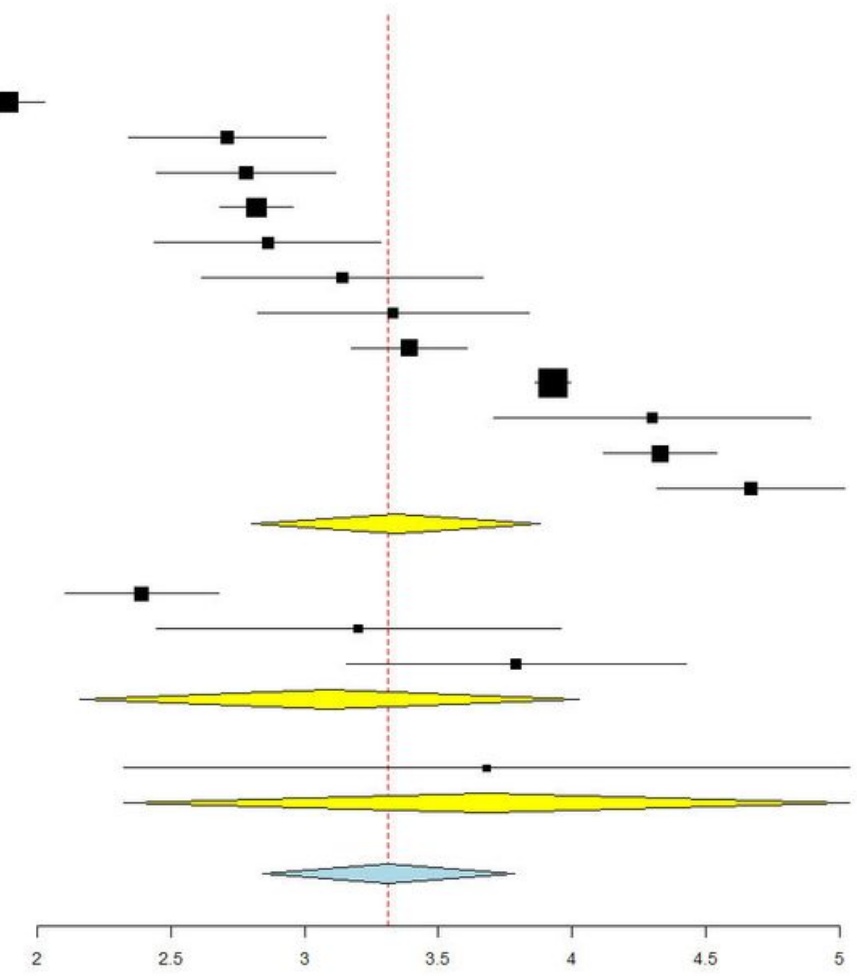


Studies

Vieira et al. [40]

Stübinger et al. [35]

Wiele et al. [27]

Cassetta et al. [25]

Vercruyssen et al. [33]d

Sun et al. [30]

Arisan et al. [42]

Vercruyssen et al. [33]b

Cassetta et al. [38]b

Cassetta et al. [36]a

Cassetta et al. [31]

Cassetta et al. [37]

Subgroup Fixed (I^2=97.81\%, P=0.00)

Vercruyssen et al. [33]c

Vercruyssen et al. [33]a

Farley et al. [41]

Cassetta et al. [38]a

Cassetta et al. [38]c

Cassetta et al. [36]b

Subgroup Non-fixed $\left(I^{\wedge} 2=95.49 \%, P=0.00\right)$

Overall $\left(I^{\wedge} 2=97.38 \%, P=0.00\right)$
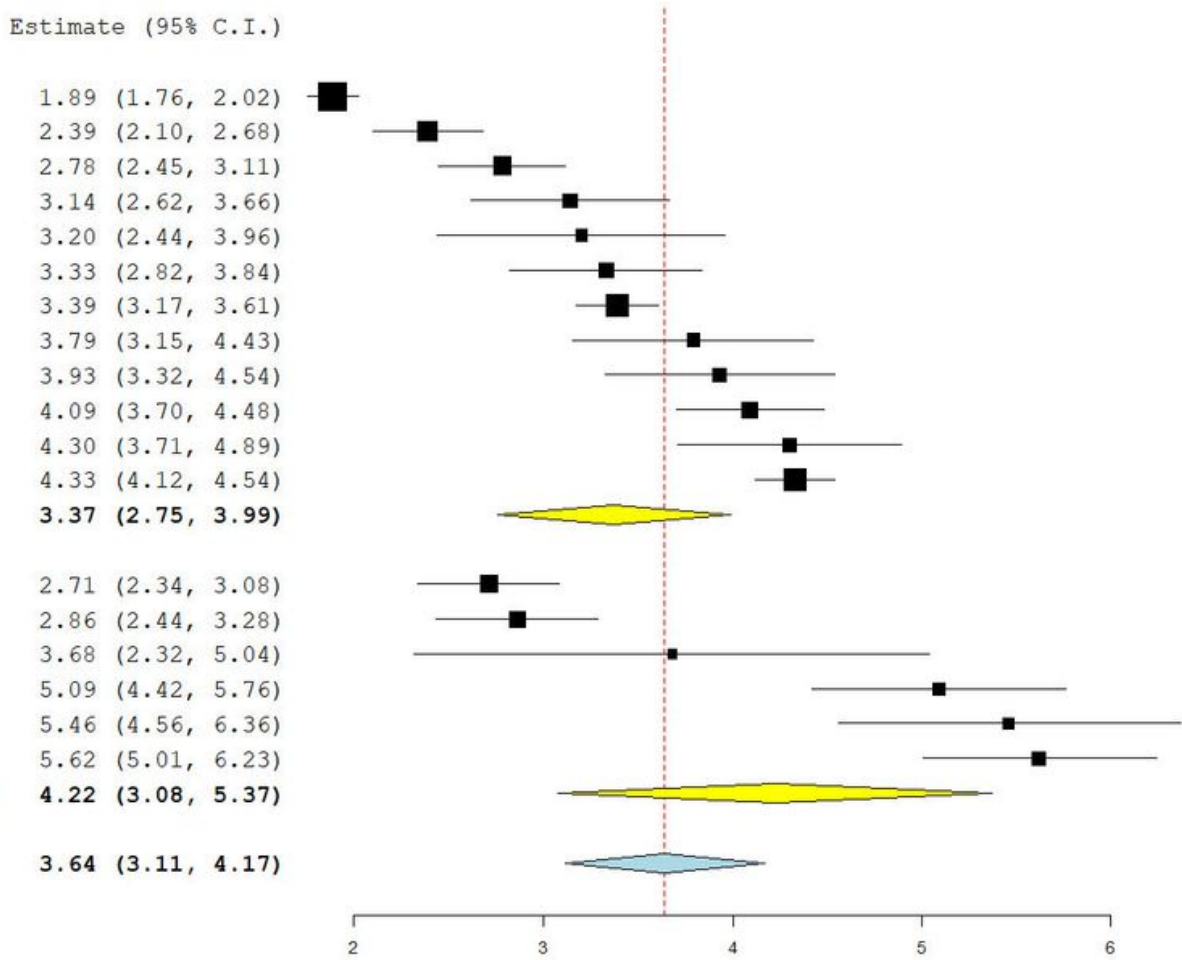

\section{Figure 20}

Angular deviation of implant axis, categorized by guide fixation method

\begin{tabular}{lrrr} 
Studies & \multicolumn{2}{c}{ Estimate (95\% C.I.) } \\
Farley et al. [41] 2013 & -1.51 & $(-2.14,-0.88)$ \\
Verhamme et al. [29] 2015 & -0.84 & $(-0.92,-0.76)$ \\
Verhamme et al. [28] 2015 & -0.58 & $(-0.61$, & $-0.55)$ \\
Ochi et al. [39] 2013 & -0.28 & $(-0.50$, & $-0.06)$ \\
Stübinger et al. [35] 2014 & 0.47 & $(0.34$, & $0.60)$ \\
Wiele et al. [27] 2015 & 0.48 & $(0.37$, & $0.59)$ \\
Sun et al. [30] 2015 & 0.83 & $(0.67$, & $0.99)$ \\
Cassetta et al. [38] 2013 & 0.86 & $(0.78$, & $0.94)$ \\
Vercruyssen et al. [32] 2015 & 0.90 & $(0.79$, & $1.01)$ \\
Lee et al. [26] 2016 & 0.93 & $(0.77$, & $1.09)$ \\
& & & \\
Overall (|^2=99.66 \% , P< 0.01) & $\mathbf{0 . 1 5}$ & $(-0.36$, & $0.66)$
\end{tabular}

Figure 21 


\begin{tabular}{|c|c|c|c|}
\hline Studies & Estin & nate $(95$ & C.I.) \\
\hline Farley et al. [41] & -1.51 & $(-2.14$, & $-0.88)$ \\
\hline Verhamme et al. [29] & -0.84 & $(-0.92$, & $-0.76)$ \\
\hline Verhamme et al. [28] & -0.58 & $(-0.61$, & $-0.55)$ \\
\hline Ochi et al. [39] & -0.28 & $(-0.50$, & $-0.06)$ \\
\hline Wiele et al. [27] & 0.48 & (0.37, & $0.59)$ \\
\hline Vercruyssen et al. [32]a & 0.74 & $(0.59$, & $0.89)$ \\
\hline Vercruyssen et al. [32]c & 0.74 & $(0.56$, & $0.92)$ \\
\hline Sun et al. [30] & 0.83 & $(0.67$, & $0.99)$ \\
\hline Lee et al. [26] & 0.93 & $(0.77$, & $1.09)$ \\
\hline Subgroup Flapless $\left(\left.\right|^{\wedge} 2=99.43 \%, P=0.00\right)$ & 0.08 & $(-0.40$, & $0.56)$ \\
\hline Stübinger et al. [35] & 0.47 & $(0.34$, & $0.60)$ \\
\hline Vercruyssen et al. [32]d & 1.00 & $(0.81$, & 1.19) \\
\hline Vercruyssen et al. [32]b & 1.18 & $(0.93$, & $1.43)$ \\
\hline Subgroup Open $\left(I^{\wedge} 2=94.38 \%, P=0.00\right)$ & 0.87 & $(0.42 ，$ & 1.33) \\
\hline Overall $\left(I^{\wedge} 2=99.43 \%, P=0.00\right)$ & 0.28 & $(-0.16$, & $0.72)$ \\
\hline
\end{tabular}

\section{Figure 22}

Linear deviation of implant depth categorized by surgical technique

\begin{tabular}{|c|c|c|c|}
\hline Studies & Estin & late $195^{\circ}$ & C.I.) \\
\hline Farley et al. [41] & -1.51 & $(-2.14$, & $-0.88)$ \\
\hline Verhamme et al. [29] & -0.84 & $(-0.92$, & $-0.76)$ \\
\hline Verhamme et al. [28] & -0.58 & $(-0.61$, & $-0.55)$ \\
\hline Ochi et al. [39] & -0.28 & $(-0.50$, & $-0.06)$ \\
\hline Stübinger et al. [35] & 0.47 & $(0.34$ & $0.60)$ \\
\hline Wiele et al. [27] & 0.48 & (0.37, & $0.59)$ \\
\hline Cassetta et al. [38]c & 0.63 & $(0.52$, & $0.74)$ \\
\hline Vercruyssen et al. [32]c & 0.74 & (0.56, & $0.92)$ \\
\hline Sun et al. [30] & 0.83 & (0.67, & $0.99)$ \\
\hline Cassetta et al. [38]b & 0.85 & $(0.69$, & 1.01) \\
\hline Lee et al. [26] & 0.93 & (0.77, & 1.09) \\
\hline Vercruyssen et al. [32]d & 1.00 & $(0.81$, & 1.19) \\
\hline Subgroup Fully guided $\left(I^{\wedge} 2=99.48 \%, P=0.00\right)$ & 0.25 & $(-0.19$ & $0.68)$ \\
\hline Vercruyssen et al. [32]a & 0.74 & $(0.59$ & $0.89)$ \\
\hline Cassetta et al. [38]a & 0.98 & $(0.85$, & 1.11) \\
\hline Vercruyssen et al. [32]b & 1.18 & $(0.93$, & 1.43) \\
\hline Subgroup Half guided $\left(I^{\wedge} 2=80.71 \%, P=0.01\right)$ & 0.95 & $(0.73$, & 1.17) \\
\hline Overall $\left(I^{\wedge} 2=99.5 \%, P=0.00\right)$ & 0.39 & $(-0.02$ & $0.80)$ \\
\hline
\end{tabular}
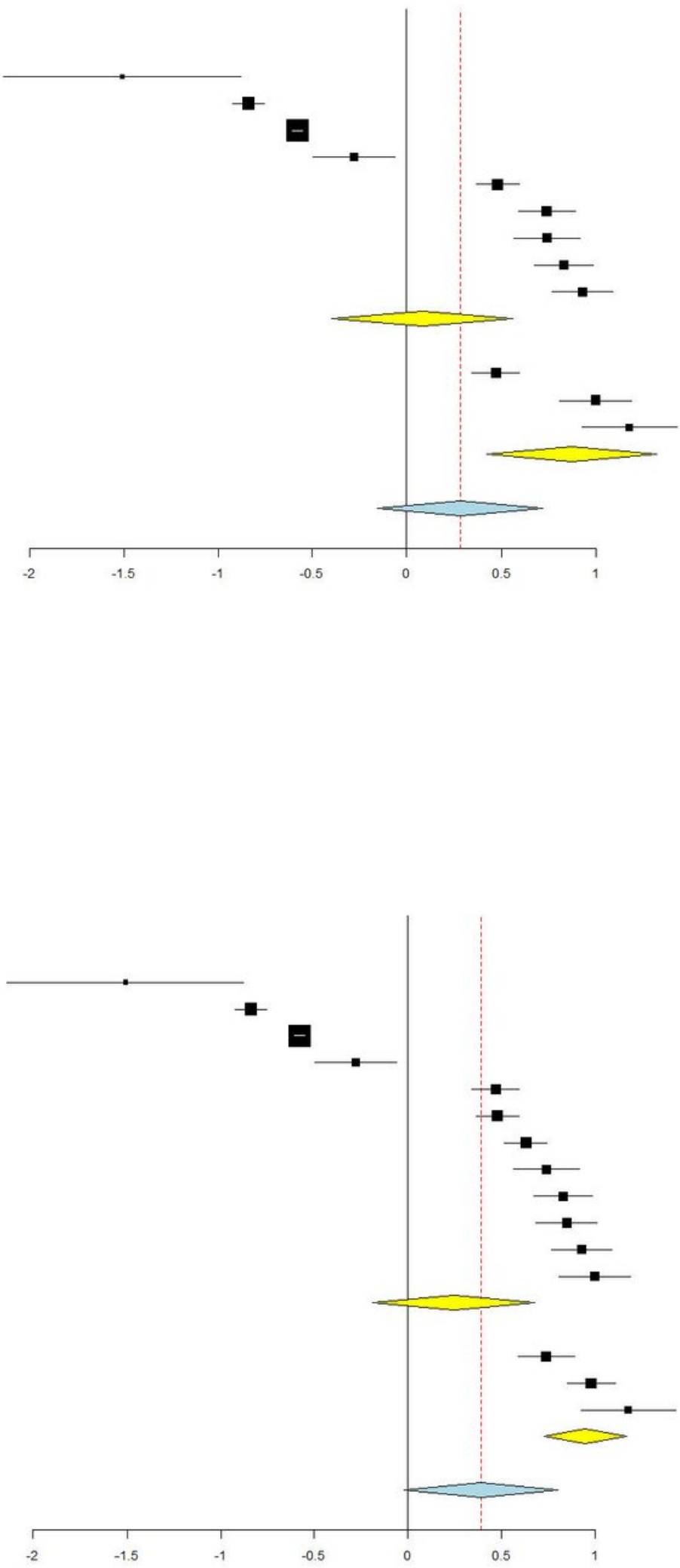

Figure 23 


Studies
Verhamme et al. [29]
Verhamme et al. [28]
Sun et al. [30]a
Subgroup Maxilla $\left(\left.\right|^{\wedge} 2=99.61 \%, P=0.00\right)$
Ochi et al. [39]
Sun et al. [30]b
Subgroup Mandible $\left(\left.\right|^{\wedge} 2=97.88 \%, P=0.00\right)$
Overall $\left(\left.\right|^{\wedge} 2=99.35 \%, P=0.00\right)$

Studies

Verhamme et al. [29]

un et al. [30]

作

$$
\begin{aligned}
& \text { Estimate (95\% C.I.) } \\
& -0.84(-0.92,-0.76) \\
& -0.58(-0.61,-0.55) \\
& 0.65 \quad(0.54,0.76) \\
& -0.26(-0.91,0.39) \\
& -0.28(-0.50,-0.06) \\
& 1.04 \quad(0.73, \quad 1.35) \\
& 0.38(-0.92,1.67) \\
& -0.01(-0.54,0.51)
\end{aligned}
$$

\begin{tabular}{|c|c|c|c|}
\hline Studies & Estin & nate $195 \%$ & C.I.) \\
\hline Farley et al. [41] & -1.51 & $(-2.14$ & $-0.88)$ \\
\hline Lee et al. [26] & 0.93 & $(0.77$ & 1.09) \\
\hline Subgroup Teeth $\left(I^{\wedge} 2=98.14 \%, P=0.00\right)$ & -0.27 & $(-2.66$ & 2.12) \\
\hline Verhamme et al. [29] & -0.84 & $(-0.92$ & $-0.76)$ \\
\hline Verhamme et al. [28] & -0.58 & $(-0.61$ & $-0.55)$ \\
\hline Ochi et al. [39] & -0.28 & $(-0.50$ & $-0.06)$ \\
\hline Wiele et al. [27] & 0.48 & (0.37, & $0.59)$ \\
\hline Vercruyssen et al. [32]a & 0.74 & (0.59, & $0.89)$ \\
\hline Vercruyssen et al. [32]c & 0.74 & $(0.56$, & $0.92)$ \\
\hline Sun et al. [30] & 0.83 & $(0.67$, & $0.99)$ \\
\hline Subgroup Mucosa $\left(\left.\right|^{\wedge} 2=99.46 \%, P=0.00\right)$ & 0.15 & $(-0.35$ & $0.66)$ \\
\hline Stübinger et al. [35] & 0.47 & $10.34 ，$ & $0.60)$ \\
\hline Vercruyssen et al. [32]d & 1.00 & $(0.81$, & 1.19) \\
\hline Vercruyssen et al. [32]b & 1.18 & $(0.93$, & 1.43) \\
\hline Subgroup Bone $\left(I^{\wedge} 2=94.38 \%, P=0.00\right)$ & 0.87 & $(0.42 ，$ & 1.33) \\
\hline Overall $\left(I^{\wedge} 2=99.43 \%, P=0.00\right)$ & 0.28 & $(-0.16$, & $0.72)$ \\
\hline
\end{tabular}

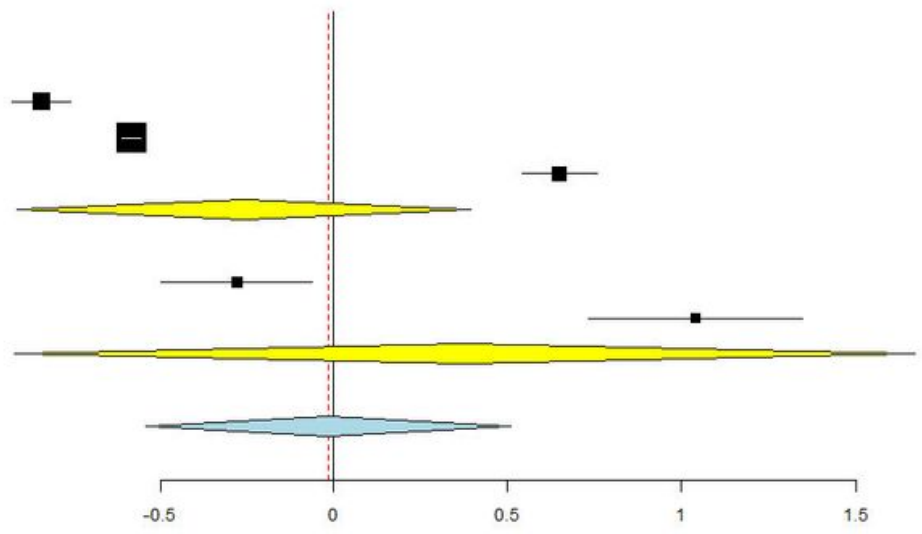

\section{Figure 24}

Linear deviation of implant depth categorized by jaw.

Figure 25

Linear deviation of implant depth, categorized by type of guide support tissue 


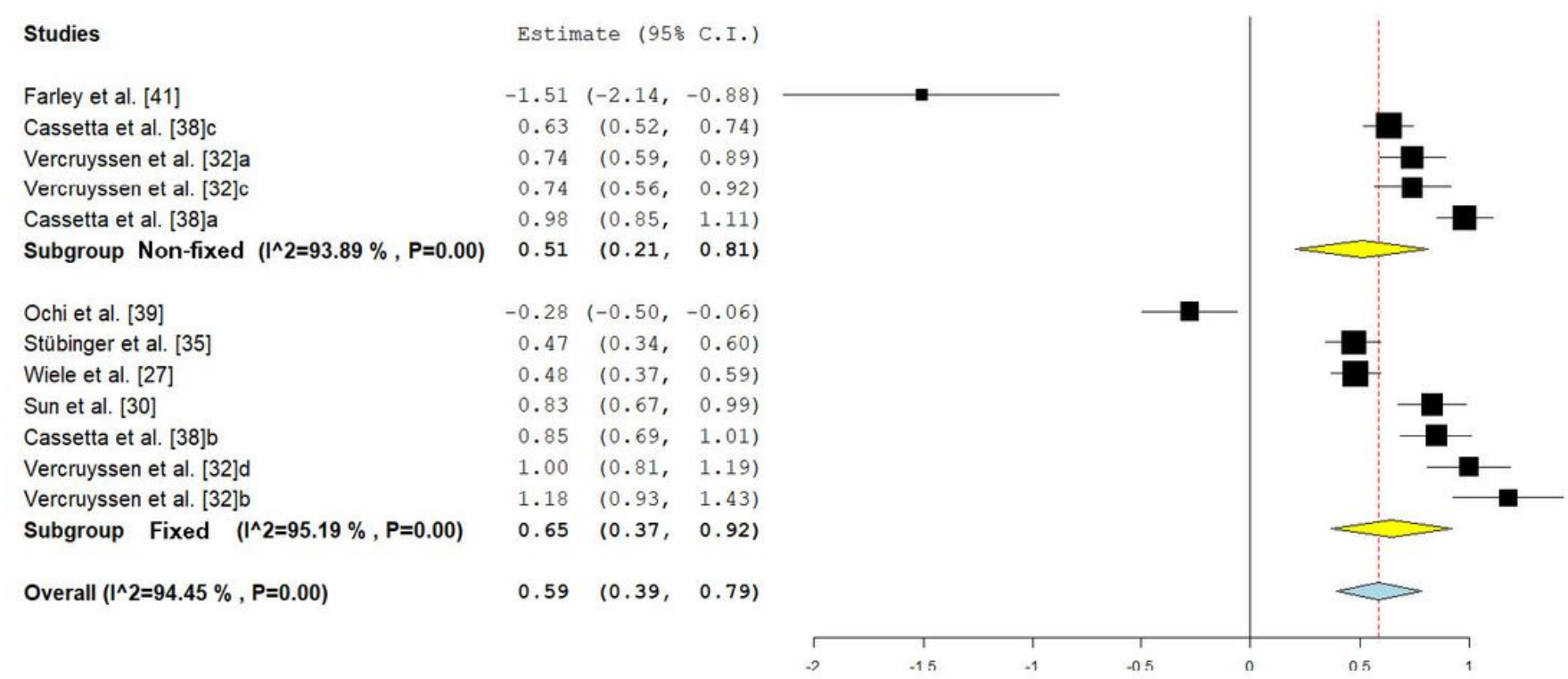

Figure 26

Linear deviation of implant depth categorized by guide fixation method 